\title{
Plan Colombia's Onset: Effects on Homicides and Violent Deaths*
}

Recibido: Mayo 27 de 2013 - Aceptado: Mayo 29 de 2014

Doi: dx.doi.org/10.12804/rev.econ.rosario.17.01.2014.05

\author{
Gerson Javier Pérez V. ${ }^{\dagger}$ \\ Centro de Estudios Económicos Regionales (CEER) \\ Banco de la República - Cartagena, Colombia
}

\begin{abstract}
In this paper, the link between Plan Colombia and violence is explored. This paper exploits the difference in the success of the program among the different regions to identify the potential side effects on homicides and violent deaths. Results show no significant effects observed on homicides. On the other hand, evidence was found of increases in the number of violent deaths for women living in urban areas, and an opposite negative effect for men living in rural areas. These findings are consistent for different specifications of the model, the cut-off end of the program, and the classification of the regions' criteria.
\end{abstract}

JEL Classification: R10, H5, K1.

Keywords: homicides; regional analysis; Plan Colombia.

* I am grateful to Marco Francesconi, Patrick Nolen, Olivier Marie, Joao Santos-Silva, Adolfo Meisel and two anonymous reviewers for their useful comments about previous versions of this paper.

+ Economist at Centro de Estudios Económicos Regionales (CEER) - Banco de la República. The opinions expressed here are those of the authors and not necessarily of the Banco de la República, the Colombian Central Bank, nor of its Board of Directors. Any remaining errors are my own. For comments please write to gjavierperezv@gmail.com, Tel (57 5) 6600808 Ext 5347.

Para citar este artículo: Pérez V. J. (2014). Plan Colombia's Onset: Effects on Homicides and Violent Deaths. Revista de Economía del Rosario, 17(1), 119-156. doi: dx.doi.org/10.12804/rev. econ.rosario.17.01.2014.05 


\title{
Inicio del Plan Colombia: efectos en homicidios y muertes violentas
}

\begin{abstract}
Resumen
En este documento se analiza la relación entre el Plan Colombia y la violencia. Este artículo explota las diferencias regionales del éxito del programa para identificar los efectos potenciales sobre los homicidios y las muertes violentas. Los resultados muestran efectos no significativos en los homicidios. Por otro lado, se encontraron evidencias de aumentos en el número de muertes violentas para el caso de las mujeres que habitan las áreas urbanas, y el efecto contrario para las que viven en las rurales. Los resultados son consistentes para diferentes especificaciones del modelo, periodos de cobertura del programa y clasificación de las regiones.
\end{abstract}

Clasificación JEL: R10, H5, K1.

Palabras clave: homicidios, análisis regional, Plan Colombia.

\section{Inicio do Plano Colômbia: efeitos em homicídios e mortes violentas}

\begin{abstract}
Resumo
Neste documento analisa-se a relação entre o Plano Colômbia e a violência. Este artigo explora as diferencias regionais de sucesso do programa para identificar os efeitos potenciais sobre os homicídios e as mortes violentas. Os resultados mostram efeitos não significativos nos homicídios. Por outro lado, se encontraram evidências de aumentos no número de mortes violentas para o caso das mulheres que moram em áreas urbanas, e o efeito contrário para as que moram nas áreas rurais. Os resultados são consistentes para diferentes especificações do modelo, períodos de cobertura do programa e classificação das regiões.
\end{abstract}

Classificação JEL: R10, H5, K1.

Palavras-chave: homicídios, análise regional, Plano Colômbia. 


\section{Introduction}

Historically, the relationship between security policies and crime has been of great interest for a number of disciplines. Becker (1968) on the one hand, and Ehrlich (1974) on the other both offer analyses where criminals make the decision to commit crimes based on the potential benefits and the probability of receiving punishment in terms of apprehensions and/or monetary compensations to society. It was only recently that the increased availability of data and the new methodologies have enabled us to unravel the elusive relationship between security policies -in terms of increased financial and human resources- and crime rates. ${ }^{1}$

Most of the literature has focused on either developed countries or on the impact of security measures adopted for fighting criminal activities in urban areas (see Di Tella and Schargrodski, 2004 for Argentina, Klick and Tabarrock, 2005 for Washington D.C., Machin and Marie, 2005 for England and Wales, and Draca et al., 2009 for London). ${ }^{2}$ Not many studies deal with these issues in developing countries, which are more likely to face both a wider range of criminal actors and higher levels of crime as such. Colombia, in particular, has been of major interest because of the coexistence of the world's oldest guerrilla group, the drug producers and dealers, and paramilitary groups as well as urban gangs. Over the past three decades, these criminals and their actions have mutated to survive despite the actions of the authorities.

The effects of the Plan Colombia program on homicides and other types of violent deaths are analyzed in this paper. ${ }^{3} \mathrm{~A}$ key feature is that the policy seems to have had disproportionate effects on the different coca producing departments. Under these conditions, various strategies were considered for looking at homicides and violent deaths in those departments with high-coca-

1 Cameron (1988) shows how researchers were handcuffed for a number of decades by their intention to resolve the dilemma with respect to the direction of causality in the relationship between police presence and crime.

2 All these studies also tried to deal with the causality problem between police presence and crime levels through quasi-experimental strategies based on terrorist actions in most of the cases.

3 The program is a Colombian initiative starting in 1999/2000 which had been partly sponsored by the American government and was intended to reduce the supply of illegal drugs, cocaine in particular. To do this, the two governments agreed that the specific target would be to cut the number of hectares of coca bushes in Colombia in half by 2005. The total investment during the first six years of the program was approximately US\$11 billion (12,5\% of Colombia's average GDP between 2000 and 2005) which was used to increase the manpower of the military and police forces, purchase and improve military equipment, and give military and human rights training. 
destruction relative to low-destruction and non-producer ones before and after the implementation of the program.

Among the most recent studies of the situation in Colombia, Angrist and Kugler (2008), Barón (2008), and Pérez (2012a,b) are the most notable. All of them looked at quasi-experiments to circumvent the corresponding endogeneity problems. Angrist and Kugler address the causal relationship between the increase in coca cultivation in the early nineties and violence as well as the potential effects on the labor market in the rural areas. They used the 1,000 hectare threshold under cultivation to classify the treatment and control groups and found consistent evidence supporting the hypothesis that more coca production brings about more violent deaths since coca supports organized criminals in rural areas.

Barón (2008) makes use of the Plan Colombia program to address the causal relationship between this program and violence, homicides, and partner abuse. To classify the treatment and control groups of departments he uses the 1,000 hectares of coca crops destroyed under the argument that this is a critical point from which coca activities might affect criminality in Colombia. The results show significant reductions in homicides in those regions where the program seems to have had stronger presence, and no significant effects on partner abuse were found.

Pérez (2012a) analyzes the Democratic Security Policy (DSP) implemented by the incoming government in 2002 and its causal effects on a wide range of crimes. There are differentiated results based on the types of crimes committed and the type of perpetrator. Strong and significant reductions were found for those crimes commonly committed by organized crime such as terrorism, kidnappings, auto-theft, and terrestrial piracy, but no effects from the policy on crimes usually committed by common criminals in urban areas such as burglaries and street robberies.

The present study contributes to the literature in several ways. Previous studies on this topic analyzed the effects of Plan Colombia on violence using data from 2000 to 2005. This strategy disregards the effect caused by an overlap with a national policy implemented during 2002/2003 (the Democratic Security Policy, DSP), a strategy for which the main purpose was to reduce criminality (homicides included). This might be causing serious upward biases on the estimates and clouding the potential real effects of the program on the outcome variables. In this paper, a post-policy period free of the overlapping effects with the DSP is used to clarify which of the effects were the real effects of the program on homicides. ${ }^{4}$

4 Another potential confounding factor avoided by choosing this period of analysis is 
The second contribution has to do with the classification of the regions into treatment and control groups. A relative measure (coca crops destroyed as a percentage of the total coca cultivation) and its distribution among the departments were used to classify the treatment and control regions. This approach naturally categorizes the two groups by means of a relative, comparable measure. I believe this strategy is stronger and a way that is even more consistent to look at the impact of economic and police resources on homicides and violent deaths. ${ }^{5}$ Additionally, the departments were classified into three groups, instead of two: high-destruction, low-destruction, and non-producers. This approach made it possible to carry out additional exercises in order to test the robustness and assumptions of the empirical approach. ${ }^{6}$

The estimates show that there is no evidence supporting the hypothesis that the implementation of Plan Colombia significantly reduced homicides although it seems to have had differentiated positive/negative effects across gender and location on violent deaths in high-coca-destruction regions relative to the lowdestruction and non-producing regions. This was the conclusion I reached after using a highly-disaggregated database for deaths and after carrying out a series of exercises and robustness checks testing for different specifications of the baseline model and different alternatives for the comparison groups.

My argument in this paper is that, whereas it is undeniable that Plan Colombia's economic resources have played an important role in enhancing security and reducing the areas under coca cultivation, it is also true that reductions in homicides were not an effect of Plan Colombia but perhaps a result of the Democratic Security Policy. ${ }^{7}$ The main purpose of this latter strategy, which was implemented by the incoming government in 2002, was to cut down on the high levels of criminality in the country. Also note that it was precisely between 1999 and 2002, four years after Plan Colombia's implementation, that crime indicators reached the highest recorded levels in the country.

the peace seeking talks between the Colombian government and the self-defense group of paramilitaries. These talks started in June 2003. The two security strategies, if not properly treated, could have given the causal effects from Plan Colombia an upward bias.

5 As mentioned before, previous studies analyzing the effects of coca crops and violence in Colombia (Angrist and Kugler, 2008 and Barón, 2008) have used subjective ways to distinguish the two groups. Specifically, they used 1,000 hectare increase and 1,000 hectare destruction of coca crops respectively. These classification strategies suffer from two main drawbacks. They are absolute and subjective measures, which might be contributing even more in obscuring the real effects of the program on the outcome variables.

6 For example, having two potential control groups made it possible to test for the uncounfoundedness assumption.

7 Contraloría General de la Nación (2001) presented a first evaluation report on the first results from Plan Colombia. More recently, GAO (2008) presented an updated report. 
The rest of the paper is organized as follows. The Plan Colombia program and its scope is briefly described in section 2. The nature of the classification of regions is explained in section 3 and some descriptive statistics of the data are provided. The empirical strategy and model are described in section 4 . In section 5, the estimates of the impact of PC on homicides and violent deaths are presented, together with some robustness exercises. Section 6 is the conclusion.

\section{Plan Colombia Program}

Between 1994 and 1999, Colombia faced a steep increase of more than $350 \%$ in coca bush cultivation as a result of the decrease in the activities of the other two major producers, Perú and Bolivia. The consequences, apart from the obvious increase in cocaine production and export, were the strengthening of the illegal armed groups and the increase in violence and crime. In 1999, just one year after the start of a new government, the Plan Colombia program was carried out for the first time.

At the beginning, the main goals of Plan Colombia were: fighting against drug production and trafficking as well as related organized crime activities, improving the economy and democratic institutions, and moving ahead on peaceseeking talks with the insurgent groups. The government specifically sought to reduce the number of hectares of coca bushes by half by 2005. At the time the program was put into effect, there were 160,100 hectares of coca cultivation. ${ }^{8}$

The strategy of the Colombian-American partnership was to focus on aerial spraying and manual coca bush destruction. Even though there were several goals in the original plan that were humanitarian and defensive in nature, the involvement and cooperation of the American government and its specific resolve to reduce the amount of cocaine entering its territory changed the main scope of the program. As a whole, the focus was changed to military matters and this has been largely criticized (Ramírez, 2005). ${ }^{9}$ With respect to this, Mejía and Restrepo (2009) show through a game theory approach that given the unlike main goals of the two governments (the Colombian and the American), the best strategies, those that either maximized the benefits or minimized the costs of the war against drug trafficking, are considerably different. For the American government, for instance, it would be optimal to focus the resources on the

8 A complete analysis of the first 10 years of Plan Colombia can be seen in Acevedo et al. (2008).

9 Deas (2002) argues in favor of the pertinence of military aid and cooperation. 
trafficking side of the problem only, whereas the Colombian government would very much prefer to concentrate on maintaining territorial control, which would mean focusing on the production side of the problem.

Assessments of the first phase of the Plan Colombia strategy showed controversial and unexpected results. Even though the Colombian-American partnership for reducing cocaine production was able to achieve the objective of a $50 \%$ reduction in coca crops, something they did not count on was the production process' adaptability to exogenous changes. As mentioned by Mejía and Restrepo (2009) and Mejía and Posada (2008), cocaine producers were able to produce virtually the same amount of coca leaf, and the corresponding amount in cocaine production even with only half of the land they had originally had. ${ }^{10}$ What this means is that even though Plan Colombia was effective in accomplishing the means to achieve the main target, it was not successful in reaching the target itself. The authors also note that the adaptation was such that the availability of cocaine as well as its international price remained unchanged after all these joint efforts. In a more recent study, after a deep analysis of the cocaine production links, Gaviria and Mejía (2011) concluded that the anti-drug policy formulated by the Americans and applied by the Colombian government had failed and should be changed. In general, they emphasized the necessity for more scientifically-based policies to deal with the anti-drug problem instead of ideological misconceptions around prohibition or legalization.

In terms of financial resources spent, during the first six years of the program a total of US $\$ 11$ billion, where the Colombian tax-payers faced $65 \%$ of the cost and the Americans covered the remaining 35\%, were invested to tackle the drug trafficking problem head-on. Most of these resources were spent on the modernization of military equipment and training, the increase in the number of servicemen in the forces, and human rights training. ${ }^{11}$

\section{Classification of Regions}

Regionally, Colombia is divided into 32 departments and the capital city. Of these, more than half have been affected by coca cultivation in recent decades.

10 The number of hectares used to cultivate coca bushes in particular went from 163,300 to 78,000 between 2000 and 2006 while potential manufacturing of cocaine declined only about $14 \%$ as it went from 695 to 610 metric tons in the same period of time (UNODC, 2009). This result comes from the fact that while in $2000,4.3 \mathrm{~kg}$ were produced per hectare per year, in 2006, 7.7 were produced on the same tract of land (Mejía and Restrepo, 2009).

11 The number of uniformed police officers per 100,000 inhabitants increased from 191 in 1999 to 217 in 2005. 
Apart from the particular type of soil required to grow coca leaf, other factors such as the distance to populous urban areas and road infrastructure affect coca cultivation by making it more difficult to both detect and eradicate (Rocha et al, 2010). ${ }^{12}$ These authors also mention proximity to water sources as a factor determining the location of coca crops.

In this paper, I make use of the fact that even though Plan Colombia is a national program, it has had disproportionate regional effects on the country. This identification strategy, in particular, is based on the different results obtained from the coca eradication program in the different regions between 2000 and 2002. A total of 29 regions (covering 33 of the departments), of which 23 have been officially reported as having significant levels of coca cultivation, are considered in this study. A fundamental issue for both the identification and the empirical strategy is the belief that it was an exogenous change in the international coca crop location that caused the implementation of Plan Colombia. In fact, in the mid 1990s in an attempt to stop, or at least to reduce, the transit of coca leaf from the two largest producers at the time, Perú and Bolivia, to the processing laboratories in Colombia, local authorities together with the American government adopted a military strategy consisting of blocking aircraft trying to reach Colombian territory. ${ }^{13}$

In order to identify the treatment and control groups, I analyzed how successful the program was between 2000 and 2002 in terms of the coca bush destruction. Previous studies have used subjective ways of deciding on the treatment and control groups. For example, Barón (2008) sets a 1,000 hectare threshold of coca bushes destroyed under which the high/low destruction regions were specified. ${ }^{14}$ I used a less subjective definition based on the distribution of the coca crop destruction as an alternative. Figure 1 shows that there is a clearer cut off point dividing the two groups of departments - treatment and control - in terms of their success in fighting coca leaf production. Those departments, in particular, in which more than $19 \%$ of existing coca crops were destroyed between 2000 and 2002, will be considered the high-destruction or treatment group (Bolívar, Boyacá, Caquetá, Cauca, Cesar, Chocó, Córdoba,

12 Echandía (1997), Rubio (2000), and more recently Díaz and Sánchez (2004), offer the regional extent of criminal violence in Colombia during the nineties. Peceny and Durnan (2006) present the relationship between guerrillas, crime, and the U.S. antidrug policies for the same period of time.

13 A more detailed analysis of this strategy can be seen in Kawell (2001).

14 According to the author, this definition rests on the belief that this is a turning point that set apart the effects on violence. 
Cundinamarca, Putumayo, Santander, and Valle) while the remaining departments comprise the low-destruction or control group..$^{15}$

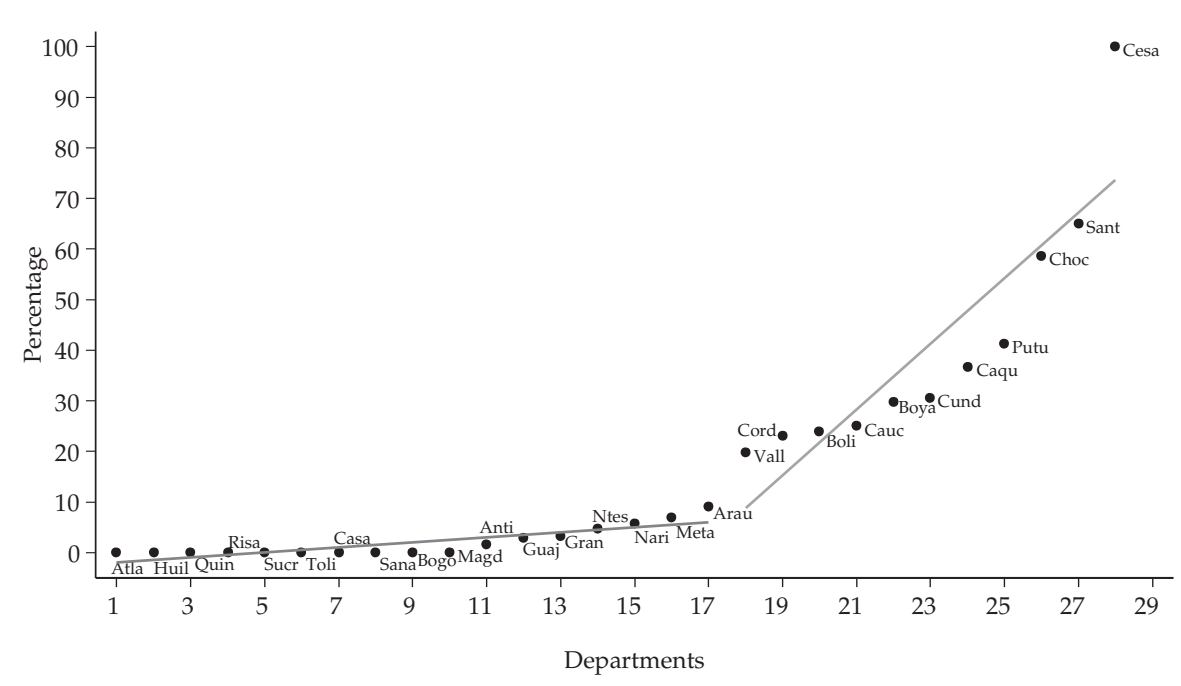

Figure 1. Achievements of Plan Colombia Program (Coca Bushes Destroyed in Producing Departments)

Note: United Nations office for Drug Control (UNODC). Based on coca cultivation and destruction carried out between 2000 and 2002.

Table 1. Coca Cultivation in Colombia

\begin{tabular}{|c|c|c|c|c|c|c|}
\hline & \multirow{3}{*}{ Departments } & \multicolumn{3}{|c|}{ Coca crops (ha) } & \multirow{2}{*}{$\begin{array}{c}\text { Total } \\
\text { destruction (ha) }\end{array}$} & \multirow{2}{*}{$\begin{array}{c}\text { Destruction } \\
(\%)\end{array}$} \\
\hline & & 2000 & 2001 & 2002 & & \\
\hline & & (1) & (2) & (3) & (4) & (5) \\
\hline \multirow{6}{*}{$\begin{array}{l}\text { High } \\
\text { destruction }\end{array}$} & Bolívar & 5,960 & 4,824 & 2,735 & 3,225 & $23.9 \%$ \\
\hline & Boyacá & 322 & 245 & 118 & 204 & $29.8 \%$ \\
\hline & Caquetá & 26,603 & 14,516 & 8,412 & 18,191 & $36.7 \%$ \\
\hline & Cauca & 4,576 & 3,139 & 2,120 & 2,456 & $25.0 \%$ \\
\hline & Cesar & 779 & 0 & 0 & 779 & $100.0 \%$ \\
\hline & Chocó & 250 & 354 & 0 & 354 & $58.6 \%$ \\
\hline
\end{tabular}

15 The control group of departments consists of departments with low levels of coca crop destruction (Antioquia, La Guajira, Norte de Santander, Nariño, Meta, Arauca, Magdalena and Gran Amazonía), and non-producing departments (Atlántico, Huila, Quindío, Risaralda, Sucre, Tolima, Casanare, San Andrés Island, and the capital city Bogotá, D.C). 


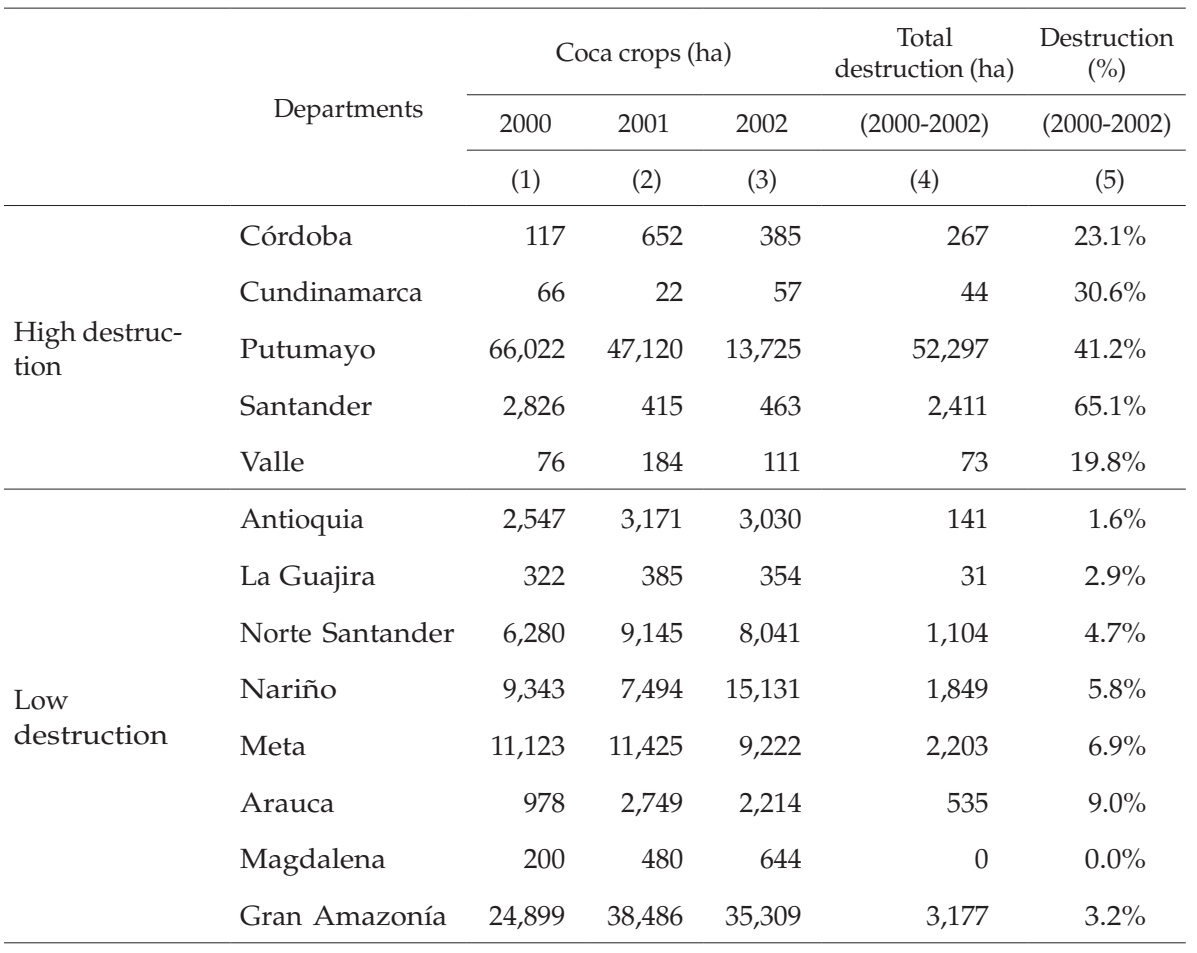

Note: United Nations office for Drug Control (UNODC). Gran Amazonía corresponds to the aggregation of five departments: Amazonía, Guaviare, Guainía, Vaupés and Vichada. Column 4 corresponds only to the number of hectares destroyed. For example for Valle, there was no destruction between 2000 and 2001, but there was between 2001 and $2002(184-111=73)$. Column 5 is computed as the total destroyed as a percentage of the total cultivation during the same period $(73 / 371=0.198)$.

Table 1 shows the number of hectares with coca bushes in producing departments between 2000 and 2002 (columns 1 through 3), the number of hectares destroyed (column 4), and the percentage of destruction relative to the total cultivation between 2000 and 2002 (column 5). The table shows this information for two groups of departments; the first group (high-destruction) corresponds to those departments where Plan Colombia seems to have been successful in destroying coca crops, whereas the second (low-destruction) is the group for which there was a modest reduction, or even an increase, between 2000 and 2002. In fact, table 1 provides some evidence of displacement of coca cultivation in the different producing departments.

For example, notice that in most of the high-destruction departments, there was a sustained reduction in cultivation while in the low-destruction regions, there was (between 2000 and 2001) an increase first and then (between 2001 and 2002) a decrease in cultivation. This significantly reduced the percentage of total destruction for this second group. This 'displacement effect' might be evidence 
of the first attempt by the coca producers to survive in the new conditions under Plan Colombia's strategies. As shown in Pérez (2012a), a second and yet more effective way to survive this Colombian/American attempt to reduce the supply of illicit drugs was to increase the productivity by doubling the amount of cocaine produced on half of the land.

Pressure from the government, in terms of manual and aerial destruction under Plan Colombia, is how the goal of reducing the total area under coca cultivation was reached. As expected, the highest reductions achieved between 2000 and 2002 were in the major producing departments, Putumayo and Caquetá, where the number of hectares went from 66,022 ha to 13,725 ha, and from 26,603 ha to 8,412 ha respectively. In general, the government managed to reduce national coca cultivation from 163,000 ha to 102,000 ha through the program during this period. This significant reduction showed its commitment to the war against drug production and trafficking.

Table 2. Pre and Post-Policy Homicide Rates

\begin{tabular}{|c|c|c|c|c|c|c|c|c|c|}
\hline \multirow{4}{*}{ Departments } & \multicolumn{3}{|c|}{ Total } & \multicolumn{3}{|c|}{ Urban Area } & \multicolumn{3}{|c|}{ Rural Area } \\
\hline & \multirow{2}{*}{$\begin{array}{c}\text { Pre-Policy } \\
1998\end{array}$} & \multicolumn{2}{|c|}{ Post-policy } & \multirow{2}{*}{$\begin{array}{c}\text { Pre-Policy } \\
1998\end{array}$} & \multicolumn{2}{|c|}{ Post-policy } & \multirow{2}{*}{$\begin{array}{c}\text { Pre-Policy } \\
1998\end{array}$} & \multicolumn{2}{|c|}{ Post-policy } \\
\hline & & 2002 & 2003 & & 2002 & 2003 & & 2002 & 2003 \\
\hline & (1) & (2) & (3) & (4) & (5) & (6) & (7) & (8) & (9) \\
\hline $\begin{array}{l}\text { High- } \\
\text { destruction }\end{array}$ & 81 & 107 & 90 & 85 & 107 & 91 & 64 & 87 & 4 \\
\hline Bolívar & 33 & 45 & 53 & 37 & 48 & 57 & 21 & 27 & 35 \\
\hline Boyacá & 37 & 52 & 48 & 35 & 52 & 47 & 35 & 48 & 47 \\
\hline Caquetá & 249 & 343 & 173 & 238 & 315 & 155 & 231 & 343 & 171 \\
\hline Cauca & 80 & 106 & 84 & 103 & 145 & 104 & 61 & 75 & 65 \\
\hline Cesar & 57 & 175 & 137 & 63 & 163 & 140 & 46 & 187 & 116 \\
\hline Chocó & 53 & 62 & 46 & 91 & 82 & 53 & 24 & 29 & 19 \\
\hline Córdoba & 26 & 39 & 29 & 35 & 52 & 36 & 17 & 20 & 18 \\
\hline Cundinamarca & 55 & 74 & 66 & 38 & 56 & 48 & 76 & 94 & 92 \\
\hline Putumayo & 230 & 184 & 199 & 353 & 164 & 205 & 113 & 166 & 175 \\
\hline Santander & 64 & 65 & 56 & 63 & 55 & 46 & 64 & 67 & 64 \\
\hline Valle & 134 & 171 & 145 & 129 & 163 & 141 & 128 & 159 & 140 \\
\hline $\begin{array}{l}\text { Low- } \\
\text { destruction }\end{array}$ & 93 & 111 & 83 & 90 & 92 & 67 & 90 & 125 & 101 \\
\hline Antioquia & 176 & 195 & 119 & 179 & 147 & 84 & 160 & 176 & 126 \\
\hline
\end{tabular}




\begin{tabular}{|c|c|c|c|c|c|c|c|c|c|}
\hline \multirow{4}{*}{ Departments } & \multicolumn{3}{|c|}{ Total } & \multicolumn{3}{|c|}{ Urban Area } & \multicolumn{3}{|c|}{ Rural Area } \\
\hline & \multirow{2}{*}{$\begin{array}{c}\text { Pre-Policy } \\
1998\end{array}$} & \multicolumn{2}{|c|}{ Post-policy } & \multirow{2}{*}{$\begin{array}{c}\text { Pre-Policy } \\
1998\end{array}$} & \multicolumn{2}{|c|}{ Post-policy } & \multirow{2}{*}{$\begin{array}{c}\text { Pre-Policy } \\
1998\end{array}$} & \multicolumn{2}{|c|}{ Post-policy } \\
\hline & & 2002 & 2003 & & 2002 & 2003 & & 2002 & 2003 \\
\hline & (1) & (2) & (3) & (4) & (5) & (6) & (7) & (8) & (9) \\
\hline La Guajira & 52 & 117 & 95 & 83 & 160 & 138 & 14 & 52 & 36 \\
\hline Norte Santander & 93 & 234 & 169 & 102 & 226 & 146 & 67 & 170 & 140 \\
\hline Nariño & 31 & 63 & 42 & 42 & 72 & 41 & 20 & 51 & 38 \\
\hline Meta & 115 & 142 & 145 & 107 & 97 & 103 & 90 & 190 & 175 \\
\hline Arauca & 126 & 270 & 228 & 141 & 288 & 216 & 101 & 212 & 212 \\
\hline Magdalena & 72 & 98 & 93 & 85 & 103 & 95 & 49 & 78 & 75 \\
\hline Gran Amazonía & 107 & 82 & 61 & 118 & 88 & 64 & 70 & 59 & 50 \\
\hline Non-Producing & 69 & 72 & 60 & 62 & 61 & 51 & 90 & 127 & 108 \\
\hline Atlántico & 44 & 49 & 57 & 46 & 47 & 56 & 17 & 36 & 45 \\
\hline Bogotá D.C. & 58 & 40 & 34 & 55 & 38 & 33 & 179 & 64 & 21 \\
\hline Caldas & 127 & 188 & 119 & 118 & 172 & 101 & 139 & 216 & 147 \\
\hline Huila & 70 & 119 & 96 & 60 & 96 & 68 & 73 & 140 & 128 \\
\hline Quindío & 90 & 105 & 94 & 87 & 94 & 92 & 86 & 150 & 80 \\
\hline Risaralda & 140 & 162 & 132 & 124 & 142 & 117 & 168 & 174 & 154 \\
\hline Sucre & 39 & 54 & 54 & 31 & 60 & 54 & 53 & 39 & 52 \\
\hline Tolima & 58 & 89 & 66 & 48 & 71 & 46 & 68 & 120 & 102 \\
\hline Casanare & 171 & 133 & 142 & 173 & 146 & 143 & 122 & 73 & 117 \\
\hline San Andrés & 12 & 7 & 20 & 16 & 9 & 27 & 0 & 0 & 0 \\
\hline $\begin{array}{l}\text { Total Producing } \\
\text { Departments }\end{array}$ & 99 & 130 & 99 & 107 & 123 & 93 & 74 & 102 & 83 \\
\hline $\begin{array}{l}\text { Total All } \\
\text { Departments }\end{array}$ & 88 & 110 & 85 & 89 & 97 & 75 & 77 & 107 & 88 \\
\hline
\end{tabular}

Note: The table includes only the coca producing departments. The Gran Amazonía region is the aggregation of the following five departments: Amazonas, Guaviare, Guainía, Vaupés, and Vichada. High-destruction departments are those where at least $19 \%$ of the coca crops were destroyed between 2000 and 2002. Deaths and the corresponding population projections using the National Department of Statistics (DANE) as the main source.

In terms of homicides, table 2 summarizes some indicators respecting the pre and post-policy rates. Columns 1 through 3 show the results for the country as a whole; columns 4 through 6, for the urban areas; and columns 7 through 9 , for the rural areas. In order to make the comparison between the pre and postpolicy easier and to deal with the significant year to year variation in the rates, 
1998 is reported here as the pre-policy period and 2002 and 2003, as the postpolicy periods. ${ }^{16}$

Homicides rates show some interesting characteristics. First is the fact that, with few exceptions, the number of homicides per 100,000 persons continued to rise between 1998 and 2002 even though Plan Colombia had been in operation for some time. These results were found for all three groups of departments -high-destruction, low-destruction, and non-producing - and included both urban and rural areas. Reductions did not show up until 2003 when the DSP was already in operation. Second, in terms of the comparison between producing and non-producing departments, the table provides some indications that even though more homicides were committed in the coca producing departments relative to non-producing ones in the country as a whole (columns 1 through 3 ), the disaggregation into areas of residence reveals that this is only the case for the urban areas (columns 4 through 6). In contrast, for the rural ones (columns 7 through 9), the non-producing departments seem to deal with this type of crime more than the producing ones.

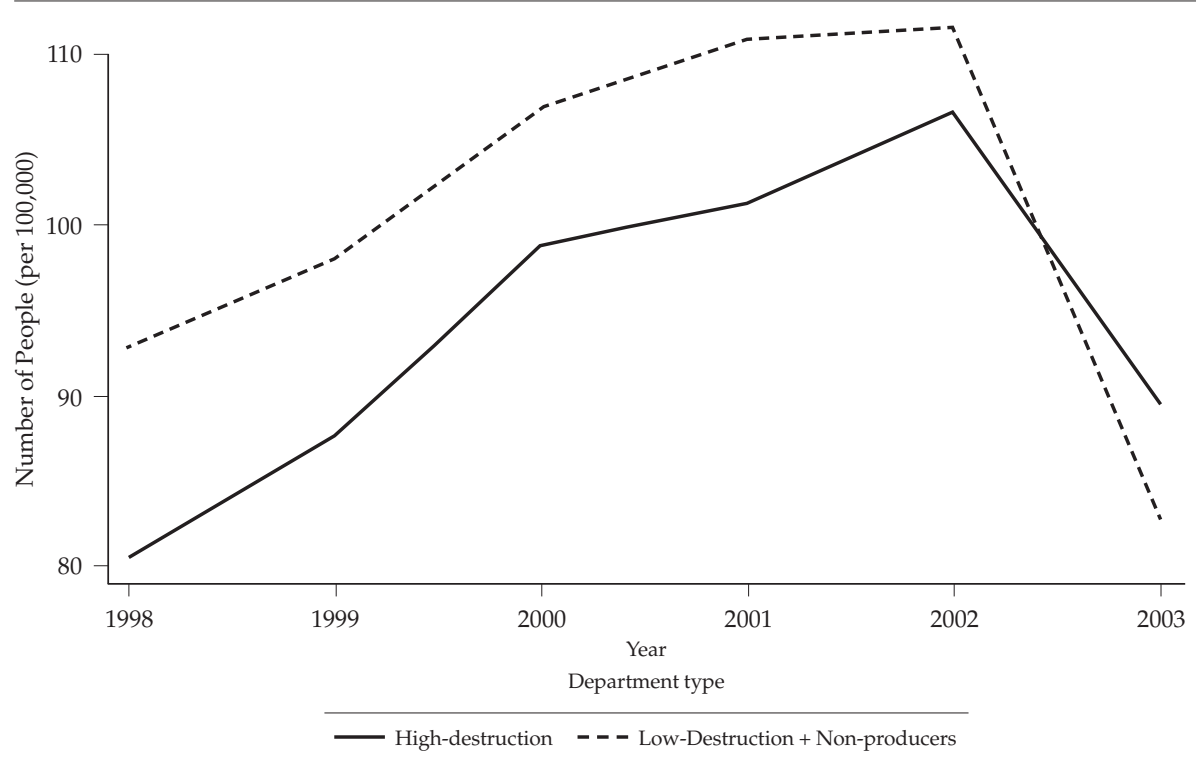

Figure 2. Homicides Rates - Men and Women Aged 15-64. (By Type of Department)

Note: Deaths and the corresponding population projections using the National Department of Statistics (DANE) as the main source.

162003 is included in table 2 as one of the post-policy years even though the post-policy period is defined as being from 2000 to 2002 for the main estimates reported in the analysis section. Nevertheless, robustness checks extended this period into 2003. 
In order to give a closer look at the dynamics of the homicide rates, figure 2 plots the comparison of the pre and post-policy trends for the treatment and control departments. During the pre-policy period (1998-1999), homicide rates for both groups show a noticeably similar upward trend which goes beyond Plan Colombia's starting point in 2000. Regarding the post-policy trends and turning points, there are two noticeable break downs which coincide with the two most recent security policies in Colombia's recent history. The first one is in 2000 and corresponds to Plan Colombia's starting point, and the second and more noticeable is in 2002, which coincides with the commencement of the DSP. Although both policies seem to be effective in reducing homicides, there is an important difference between the two. This is the fact that the turning point in 2000 did not result in a positive-to-negative change in the gradient as it did in 2002. These facts seem to offer a first indication of the argument that it was the DSP which put the economic and military resources to the best use to bring down the staggering crime levels. Nevertheless, since the new security policy started in August 2002, it seems likely that there was room for some influence by Plan Colombia in the reduction of homicides. ${ }^{17}$

Table 3. Pre and Post-Policy Violent Death Rates (excluding homicides)

\begin{tabular}{|c|c|c|c|c|c|c|c|c|c|}
\hline \multirow{4}{*}{ Departments } & \multicolumn{3}{|c|}{ Total } & \multicolumn{3}{|c|}{ Urban Area } & \multicolumn{3}{|c|}{ Rural Area } \\
\hline & \multirow{2}{*}{$\begin{array}{c}\text { Pre-Policy } \\
1998\end{array}$} & \multicolumn{2}{|c|}{ Post-policy } & \multirow{2}{*}{$\begin{array}{c}\text { Pre-Policy } \\
1998\end{array}$} & \multicolumn{2}{|c|}{ Post-policy } & \multirow{2}{*}{$\begin{array}{c}\text { Pre-Policy } \\
1998\end{array}$} & \multicolumn{2}{|c|}{ Post-policy } \\
\hline & & 2002 & 2003 & & 2002 & 2003 & & 2002 & 2003 \\
\hline & (1) & (2) & (3) & (4) & (5) & (6) & (7) & (8) & (9) \\
\hline $\begin{array}{l}\text { High- } \\
\text { destruction }\end{array}$ & 48 & 47 & 44 & 50 & 44 & 40 & 40 & 46 & 47 \\
\hline Bolívar & 24 & 22 & 20 & 28 & 24 & 22 & 12 & 13 & 11 \\
\hline Boyacá & 55 & 63 & 58 & 51 & 59 & 51 & 51 & 63 & 62 \\
\hline Caquetá & 81 & 63 & 69 & 93 & 59 & 52 & 60 & 61 & 83 \\
\hline Cauca & 51 & 52 & 56 & 70 & 64 & 61 & 34 & 42 & 50 \\
\hline Cesar & 30 & 41 & 40 & 37 & 42 & 43 & 15 & 32 & 29 \\
\hline Chocó & 28 & 31 & 27 & 41 & 42 & 33 & 17 & 16 & 9 \\
\hline Córdoba & 33 & 29 & 29 & 40 & 36 & 34 & 26 & 15 & 18 \\
\hline Cundinamarca & 55 & 59 & 53 & 50 & 48 & 44 & 55 & 72 & 66 \\
\hline Putumayo & 69 & 76 & 68 & 82 & 91 & 79 & 53 & 60 & 44 \\
\hline
\end{tabular}

17 In order to take this possibility into consideration, additional robustness checks were done by adding one additional period to include 2003. 


\begin{tabular}{|c|c|c|c|c|c|c|c|c|c|}
\hline \multirow{4}{*}{ Departments } & \multicolumn{3}{|c|}{ Total } & \multicolumn{3}{|c|}{ Urban Area } & \multicolumn{3}{|c|}{ Rural Area } \\
\hline & \multirow{2}{*}{$\begin{array}{c}\text { Pre-Policy } \\
1998\end{array}$} & \multicolumn{2}{|c|}{ Post-policy } & \multirow{2}{*}{$\begin{array}{c}\text { Pre-Policy } \\
1998\end{array}$} & \multicolumn{2}{|c|}{ Post-policy } & \multirow{2}{*}{$\begin{array}{c}\text { Pre-Policy } \\
1998\end{array}$} & \multicolumn{2}{|c|}{ Post-policy } \\
\hline & & 2002 & 2003 & & 2002 & 2003 & & 2002 & 2003 \\
\hline & (1) & (2) & (3) & (4) & (5) & (6) & (7) & (8) & (9) \\
\hline Santander & 51 & 44 & 47 & 53 & 36 & 38 & 45 & 55 & 58 \\
\hline Valle & 57 & 52 & 46 & 54 & 47 & 41 & 63 & 63 & 66 \\
\hline $\begin{array}{l}\text { Low- } \\
\text { destruction }\end{array}$ & 51 & 44 & 43 & 50 & 38 & 37 & 47 & 51 & 50 \\
\hline Antioquia & 64 & 56 & 50 & 64 & 42 & 38 & 64 & 63 & 60 \\
\hline La Guajira & 32 & 26 & 24 & 46 & 37 & 33 & 16 & 10 & 13 \\
\hline Norte Santander & 45 & 51 & 54 & 46 & 47 & 45 & 40 & 49 & 55 \\
\hline Nariño & 40 & 51 & 57 & 54 & 59 & 62 & 29 & 43 & 48 \\
\hline Meta & 76 & 61 & 65 & 71 & 46 & 55 & 53 & 65 & 52 \\
\hline Arauca & 78 & 67 & 55 & 86 & 53 & 50 & 60 & 84 & 58 \\
\hline Magdalena & 34 & 32 & 27 & 42 & 32 & 27 & 19 & 29 & 22 \\
\hline Gran Amazonía & 54 & 67 & 48 & 65 & 52 & 59 & 37 & 65 & 34 \\
\hline Non-Producers & 47 & 38 & 38 & 44 & 34 & 34 & 54 & 51 & 53 \\
\hline Atlántico & 30 & 23 & 23 & 30 & 21 & 23 & 25 & 24 & 16 \\
\hline Bogotá D.C. & 43 & 33 & 31 & 41 & 31 & 30 & 235 & 32 & 42 \\
\hline Caldas & 51 & 50 & 63 & 50 & 45 & 61 & 50 & 58 & 60 \\
\hline Huila & 76 & 66 & 63 & 75 & 67 & 55 & 74 & 60 & 67 \\
\hline Quindío & 54 & 43 & 48 & 52 & 38 & 45 & 47 & 68 & 55 \\
\hline Risaralda & 48 & 42 & 40 & 46 & 38 & 35 & 51 & 47 & 45 \\
\hline Sucre & 29 & 24 & 28 & 38 & 27 & 30 & 12 & 16 & 22 \\
\hline Tolima & 72 & 59 & 55 & 69 & 53 & 50 & 68 & 65 & 59 \\
\hline Casanare & 92 & 68 & 82 & 105 & 65 & 71 & 49 & 59 & 91 \\
\hline San Andrés & 52 & 38 & 18 & 71 & 46 & 18 & 0 & 8 & 16 \\
\hline $\begin{array}{l}\text { Total Producing } \\
\text { Departments }\end{array}$ & 51 & 49 & 46 & 53 & 44 & 41 & 42 & 48 & 47 \\
\hline $\begin{array}{l}\text { Total All } \\
\text { Departments }\end{array}$ & 50 & 45 & 43 & 50 & 40 & 38 & 44 & 49 & 48 \\
\hline
\end{tabular}

Note: The table includes only the coca producing departments. The Gran Amazonía region is the aggregation of the following five departments: Amazonas, Guaviare, Guainía, Vaupés, and Vichada. High-destruction departments are those where at least $19 \%$ of the coca crops were destroyed between 2000 and 2002. Deaths and the corresponding population projections use the National Department of Statistics (DANE) as the main source. 
For violent deaths, table 3 provides a summary of the rates at different levels of aggregation: individual departments and the aggregation of high-destruction, low-destruction, and non-producing departments. Furthermore, we find the pre and post-policy violent death rates for the national aggregation in columns 1 through 3, urban areas in columns 4 through 6, and rural areas in 7 through 9. Considering the high and low-producing aggregations, the table shows a generalized slight reduction in the number of violent deaths per 100,000 persons after the implementation of Plan Colombia with the exception of the rural areas, where the rate went from 40 to 46 in the high-increase group, and from 47 to 51 in the low-increase group between 1998-2002. Non-producing departments on the other hand show a sustained and generalized reduction in violent death rates in both urban and rural areas. As in the case of homicides, non-coca-producing departments showed fewer violent deaths than the coca-producing ones. The rural areas, where coca-producing departments seemed to face lower levels of violent deaths were again the exception.

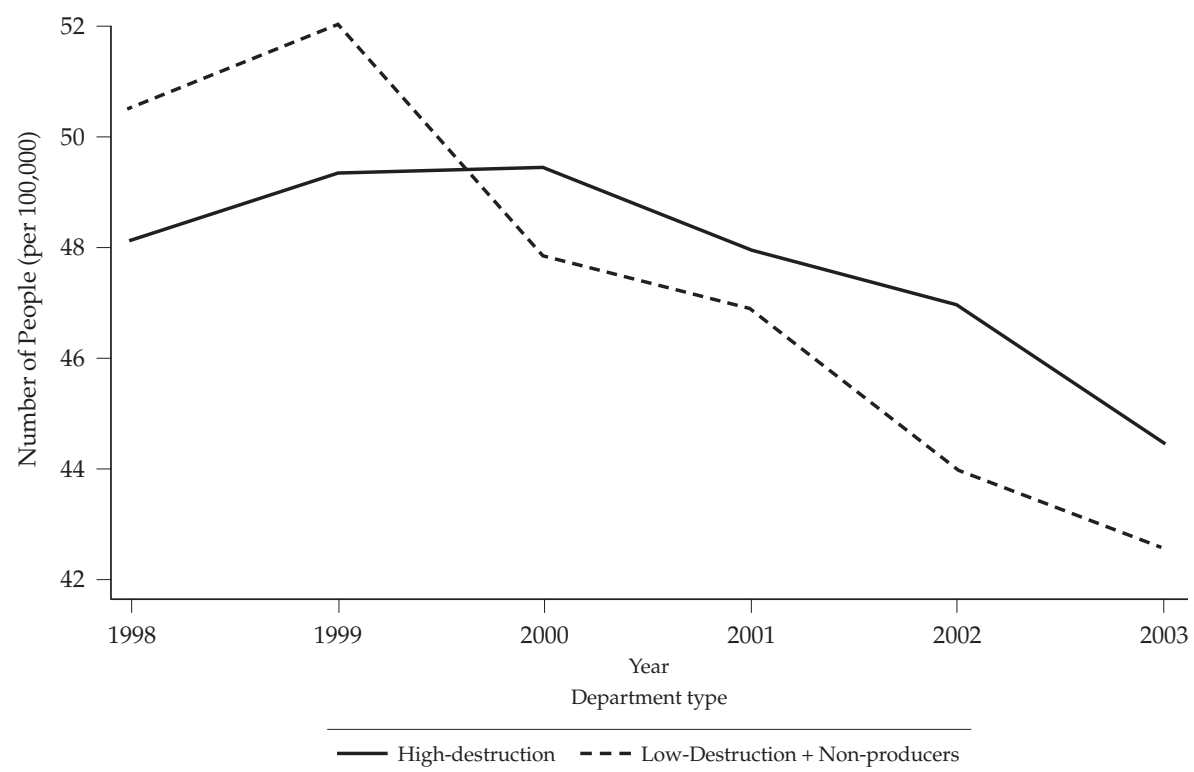

Figure 3. Violent Death Rates - Men and Women Aged 15-64. (By Type of Department) Note: Deaths and the corresponding population projections using the National Department of Statistics (DANE) as the main source.

In terms of the comparative dynamics of violent deaths for treatment and control groups in the pre and post policy period, figure 3 shows a first indication of the temporal coincidence between the reduction in the rate of violent 
deaths and the starting point of the Plan Colombia strategies. In particular, figure 3 shows a turning point in 1999 for the control group and in 2000 for the treatment group. Two characteristics supporting the identification assumption for this analysis should also be mentioned. The first is the similar pre-policy trends between the two groups, and the second is the way the post-policy is characterized by the swap of positions between the rates of the two groups.

\section{Empirical Strategy}

The aim of this study is to use the variation in the number of hectares with coca crops induced by Plan Colombia as a means of identifying its impact on homicides and violent deaths. Since there are similar pre-policy trends for treatment and control groups for both homicides and violent deaths, and given the threelevel disaggregation of the data, it is possible to work with the following specification:

$$
\frac{d_{a d t}}{p_{a d t}}=\alpha_{a}+\beta_{d}+\lambda_{t}+\delta\left(H D_{d} * P C_{t}\right)+\phi X_{d t}+\varepsilon_{a d t}
$$

where the two parts of the dependent variable $d_{\text {adt }}$ and $p_{\text {adt }}$ are the number of deaths and the population in the corresponding age group $a$, department $d$ and time $t$. In this study, variable $d$ will refer to two different types of deaths, homicides and violent deaths. The first three terms on the right hand side are defined as follows: $\alpha_{a}$ is the age effect, $\beta_{d}$ is the regional (department) effect and $\lambda_{t}$ is the time (year) effect. The fourth term is the interaction between an indicator variable for those departments with high coca-crop destruction $(H D)$, and a dummy variable for Plan Colombia's first three years of operation $(P C) .{ }^{18}$

The fifth term $X$ corresponds to a set of department/time varying controls, which includes local security expenditures and the GDP per-capita. These two variables are determined to be convenient controls for factors that could otherwise cloud the real causal effects of Plan Colombia on the outcome variables. The first one emerges from the fact that the program was thought of and put into action by the national government with the national budget. Thus, the department's own efforts to fight illegal activities could bias the Plan Colombia's

18 As mentioned before, only the first three years of Plan Colombia were considered in order to avoid overlapping with the Democratic Security Policy, implemented late in 2002. 
efforts upwards. A second general consideration that might distort the results is the difference in the degree of socioeconomic development across the different regions. In this case, the GDP per-capita is included in the model under the assumption that this indicator is capturing the socioeconomic progress. Finally, the last term on the right hand side, $\varepsilon$, corresponds to the error term. In order to control for potential omitted variable bias and serial correlation, some specifications include type-of-department (high and low-increase) time trends.

Given the particular characteristics of the outcome variables, homicides and violent death rates with discrete and nonnegative values only, it is necessary to use an estimating strategy to deal with this discreteness and nonlinearity. ${ }^{19}$ For the purpose of this paper, the Negative Binomial model is used. This is a general approach dealing with equidispersion, or the condition under which the expected value and the variance are the same). ${ }^{20}$

\section{Results and Robustness Checks}

\section{1 Homicides}

The baseline estimates of the impact of Plan Colombia on homicide rates are calculated using equation (1) and the results are listed in Table $4 .{ }^{21}$ For each of these two groups in the population (men and women), the specifications build up from a model including type-of-department specific time trends, and fixed effect dummies for age groups, departments (regions) and time (years) to another where additional controls are included.

As expected, results show no significant effect on either of the two groups in the population, men or women. The estimates are prone to take zero to positive and negative values in the more complete specifications (trends + controls), columns (2) and (4), for men and women respectively. As seen in figure 2, although the starting point for Plan Colombia in 2000 seems to have reduced the rising pattern of homicides, it does not seem to have had enough of an impact for the effects to be significantly different from zero.

19 The data have a high proportion of zeros (about $15 \%$ of the total observations). Therefore, standard linear methods are not appropriate since the data is heteroskedastic and the conditional expectation is nonlinear and positive.

${ }_{20} f(y \mid x)=\frac{\Gamma(y+\theta)}{\Gamma(y+1) \Gamma(\theta)}\left(\frac{\lambda}{\lambda+\theta}\right)^{y}\left(\frac{\theta}{\lambda+\theta}\right)^{\theta}$.

${ }^{21}$ Barón (2009) presents a very detailed analysis of homicides during the first years of Plan Colombia. This paper presents the regional extent of the problem including different socioeconomic characteristics. 
Table 4. Effects of Plan Colombia on Homicides. (National Level - Comparison of Men and Women)

\begin{tabular}{lcccc}
\hline & \multicolumn{4}{c}{ Dependent Variable: Homicide Rate } \\
\cline { 2 - 5 } & \multicolumn{3}{c}{ Men } & \multicolumn{2}{c}{ Women } \\
\cline { 2 - 5 } & Trends & Trends+Controls & Trends & Trends+Controls \\
\cline { 2 - 5 } & $(1)$ & $(2)$ & $(3)$ & $(4)$ \\
\hline \multirow{2}{*}{ Interaction term } & .072 & 0.083 & -0.124 & -0.121 \\
Trends & $(0.082)$ & $(0.084)$ & $(0.192)$ & $(0.192)$ \\
Log GDP per-capita & Yes & Yes & Yes & Yes \\
Log Local security expenditures & No & Yes & No & Yes \\
Time dummies & Yes & Yes & No & Yes \\
Department dummies & Yes & Yes & Yes & Yes \\
Age-groups dummies & Yes & Yes & Yes & Yes \\
Number of departments & 29 & 29 & 29 & Yes \\
Sample Size & 1250 & 1250 & 1250 & 29 \\
\hline
\end{tabular}

${ }^{*} \mathrm{p}<0.10,{ }^{* *} \mathrm{p}<0.05,{ }^{* * *} \mathrm{p}<0.01$

Note: The dependent variable was computed as the number of homicides per 100,000 persons aged between 15 and 64. Robust standard errors are reported in parenthesis.

Table 5. Effects of Plan Colombia on Homicides. (Urban and Rural Areas Comparisons)

\begin{tabular}{lcccc}
\hline & \multicolumn{4}{c}{ Dependent Variable: Homicide Rate } \\
\cline { 2 - 5 } & \multicolumn{3}{c}{ Men } & \multicolumn{2}{c}{ Women } \\
\cline { 2 - 5 } & Trends & Trends+Controls & Trends & Trends+Controls \\
\cline { 2 - 5 } & $(1)$ & $(2)$ & $(3)$ & $(4)$ \\
\cline { 2 - 5 } & $0.230^{* *}$ & $0.246^{* *}$ & -0.043 & -0.039 \\
Interaction term & $(0.103)$ & $(0.104)$ & $(0.255)$ & $(0.255)$ \\
Trends & Yes & Yes & Yes & Yes \\
Log GDP per-capita & No & Yes & No & Yes \\
Log Local security expenditures & No & Yes & No & Yes \\
Time dummies & Yes & Yes & Yes & Yes \\
Department dummies & Yes & Yes & Yes & Yes \\
Age-groups dummies & Yes & Yes & Yes & Yes \\
Number of departments & 29 & 29 & 29 & 29 \\
Sample Size & 1250 & 1250 & 1250 & 1250 \\
\hline
\end{tabular}




\begin{tabular}{lcccc}
\hline & \multicolumn{4}{c}{ Dependent Variable: Homicide Rate } \\
\cline { 2 - 5 } & \multicolumn{3}{c}{ Men } & \multicolumn{2}{c}{ Women } \\
\cline { 2 - 5 } & Trends & Trends+Controls & Trends & Trends+Controls \\
\cline { 2 - 5 } & $(1)$ & $(2)$ & $(3)$ & $(4)$ \\
\cline { 2 - 5 } & $-0.126($ a) & $-0.122(a)$ & -0.461 & $-0.470(0.330)$ \\
Interaction term & $(0.170)$ & $(0.170)$ & $(0.331)$ & Y. RURAL AREAS \\
Trends & Yes & Yes & Yes & Yes \\
Log GDP per-capita & No & Yes & No & Yes \\
Log Local security expenditures & No & Yes & No & Yes \\
Time dummies & Yes & Yes & Yes & Yes \\
Department dummies & Yes & Yes & Yes & Yes \\
Age-groups dummies & Yes & Yes & Yes & 29 \\
Number of departments & 29 & 29 & 29 & 1250 \\
Sample Size & 1250 & 1250 & 1250 & \\
\hline
\end{tabular}

${ }^{*} \mathrm{p}<0.10,{ }^{* *} \mathrm{p}<0.05,{ }^{* * *} \mathrm{p}<0.01$

Note: The dependent variable was computed as the number of homicides per 100,000 persons aged between 15 and 64. Robust standard errors are reported in parenthesis.

(a) Because of non-convergence in the Negative Binomial Model, the alternative Poisson estimates are reported.

Across areas of residence, table 5 shows how some differences are more noticeable including both gender and areas of residence. Although the effects are not statistically significant except for men in the urban areas where homicides seem to have increased in the treatment departments after PC started, all of the estimates are consistently negative. The program seems to have had a negative impact on homicides of men and women in the countryside and on women in urban areas. However, what is more important because of its significance and magnitude, is the situation of men living in urban areas where this type of crime increased. Note that these findings are consistent with the internal conflict in Colombia, where the rural-positioning-strategy of the most influential illegal armed groups brought about security policies that focused mostly on the rural areas and neglected general criminality in urban areas. ${ }^{22}$

So far no attention has been given to the possibility that the turning point in 2002, and the corresponding reduction in homicides, may have been due to a four-year-lagged result of Plan Colombia instead of the Democratic Security

22 For more details on urban and rural crime dynamics from the beginning to the midpoint of the $1^{\text {st }}$ decade of the $21^{\text {st }}$ century see Pérez (2012a). 
Policy. The structural change is evident when one looks at figure 2, which shows a large relative decrease in homicide rates for both the high and low-destruction departments. Although this possibility is unlikely since the coca cultivation reduction target in Plan Colombia was met from the very outset of the policy (see Appendix A), additional robustness checks were carried out in order to include this possibility.

Columns (2) and (4) of table 6 report the estimates that utilize the alternative from the 2000/2003 post-policy period compared to the initial 2000/2002 (columns 1 and 3). The results from these new specifications are interesting even though the estimates remain similar in most of the cases. ${ }^{23}$ On the one hand, there was a reduction with respect to the previous negative estimates when 2003 was included within the post-Plan Colombia period.

Table 6. Effects of Plan Colombia on Homicides. (Comparison between Two Different Post-Policy Periods)

\begin{tabular}{|c|c|c|c|c|}
\hline & \multicolumn{4}{|c|}{ Dependent Variable: Homicide Rate } \\
\hline & \multicolumn{2}{|c|}{ Men } & \multicolumn{2}{|c|}{ Women } \\
\hline & $\begin{array}{l}\text { Post-policy: } \\
2000-2002\end{array}$ & $\begin{array}{l}\text { Post-policy: } \\
2000-2003\end{array}$ & $\begin{array}{l}\text { Post-policy: } \\
2000-2002\end{array}$ & $\begin{array}{l}\text { Post-policy: } \\
\text { 2000-2003 }\end{array}$ \\
\hline & (1) & (2) & (3) & (4) \\
\hline & \multicolumn{4}{|c|}{ A. URBAN AREAS } \\
\hline \multirow{2}{*}{ Interaction term } & $0.246^{* *}$ & $0.146^{*}$ & -0.039 & 0.031 \\
\hline & $(0.104)$ & $(0.084)$ & $(0.255)$ & $(0.217)$ \\
\hline Trends & Yes & Yes & Yes & Yes \\
\hline Log GDP per-capita & Yes & Yes & Yes & Yes \\
\hline Log Local security expenditures & Yes & Yes & Yes & Yes \\
\hline Time dummies & Yes & Yes & Yes & Yes \\
\hline Department dummies & Yes & Yes & Yes & Yes \\
\hline Age-groups dummies & Yes & Yes & Yes & Yes \\
\hline Number of departments & 29 & 29 & 29 & 29 \\
\hline Sample Size & 1250 & 1500 & 1250 & 1500 \\
\hline \multirow{3}{*}{ Interaction term } & \multicolumn{4}{|c|}{ B. RURAL AREAS } \\
\hline & $-0.122(a)$ & -0.119 (a) & -0.470 & $-0.639 * *$ \\
\hline & $(0.170)$ & $(0.121)$ & $(0.330)$ & $(0.279)$ \\
\hline
\end{tabular}

23 These results have to be carefully analyzed since the number of observations is different for the two post-policy periods. 


\begin{tabular}{lcccc}
\hline & \multicolumn{4}{c}{ Dependent Variable: Homicide Rate } \\
\cline { 2 - 5 } & \multicolumn{3}{c}{ Men } & \multicolumn{2}{c}{ Women } \\
\cline { 2 - 5 } & $\begin{array}{c}\text { Post-policy: } \\
\text { 2000-2002 }\end{array}$ & \begin{tabular}{c} 
Post-policy: \\
\cline { 2 - 5 }
\end{tabular} & Post-policy: & Post-policy: \\
& $(1)$ & $(2)$ & $(3)$ & $(4)$ \\
\hline Trends & Yes & Yes & Yes & Yes \\
Log GDP per-capita & Yes & Yes & Yes & Yes \\
Log Local security expenditures & Yes & Yes & Yes & Yes \\
Time dummies & Yes & Yes & Yes & Yes \\
Department dummies & Yes & Yes & Yes & Yes \\
Age-groups dummies & Yes & Yes & Yes & Yes \\
Number of departments & 29 & 29 & 29 & 29 \\
Sample Size & 1250 & 1500 & 1250 & 1500 \\
\hline
\end{tabular}

${ }^{*} \mathrm{p}<0.10,{ }^{* *} \mathrm{p}<0.05,{ }^{* * *} \mathrm{p}<0.01$

Note: The dependent variable was computed as the number of homicides per 100,000 persons aged between 15 and 64. Robust standard errors are reported in parenthesis. Given the different number of observations used to compute the estimates in columns (1) and (2) and (3) and (4), any comparison between them must be carefully carried out.

(a) Because non-convergence in the Negative Binomial Model, the alternative Posisson estimates are reported.

On the other hand, the effect for women living in rural areas is still negative, but this time it is significant since it shows a reduction in homicides for women living in treatment departments compared with women living in control departments after the policy started. What is important from these results is that these reductions are consistent with the dynamics of homicides and other crimes which have occurred in Colombia since 2002. However, what is more important is the fact that there is still no evidence of any causal effect from Plan Colombia on reductions in homicides even four years after its implementation. This is particularly evident for men, who are more likely to be affected by conflict.

In order to cover another possible source of ambiguity in exploring the potential effects of the program on homicides, two additional criteria for choosing high and low-coca-destruction departments were defined. Table 7 shows these two new alternatives compared with the baseline definition. The first one (criterion 1 in column 1) classifies departments as high or low-destruction (or treatment and control groups) depending on whether over 1,000 hectares of coca crops were destroyed during the post-policy period. In this paper, it is used as a reference for comparison with previous studies. As a second alternative, criterion 2 in column (2) provides a measurement of the net coca bush destruction. This takes into account not only the number of hectares destroyed but 
also the new crops planted. Under this criterion, high-destruction departments are defined as those with a net destruction greater than zero. Finally, for comparison purposes, criterion 3 in column (3) shows the baseline results used in this study.

Table 7. Effects of Plan Colombia on Homicides. (Comparison between Three Different Treatment/Control Definitions)

\begin{tabular}{|c|c|c|c|}
\hline & \multicolumn{3}{|c|}{ Dependent Variable: Homicides } \\
\hline & Criterion 1 & Criterion 2 & Criterion 3 \\
\hline & (1) & (2) & (3) \\
\hline & \multicolumn{3}{|c|}{ A. NATIONAL } \\
\hline \multirow{2}{*}{ Interaction term } & -0.005 & -0.067 & 0.055 \\
\hline & $(0.077)$ & $(0.079)$ & $(0.075)$ \\
\hline Trends & Yes & Yes & Yes \\
\hline Log GDP per-capita & Yes & Yes & Yes \\
\hline Log Local security expenditures & Yes & Yes & Yes \\
\hline Time dummies & Yes & Yes & Yes \\
\hline Department dummies & Yes & Yes & Yes \\
\hline Age-groups dummies & Yes & Yes & Yes \\
\hline Number of departments & 29 & 29 & 29 \\
\hline \multirow[t]{2}{*}{ Sample Size } & 1250 & 1250 & 1250 \\
\hline & \multicolumn{3}{|c|}{ B. URBAN AREAS } \\
\hline \multirow{2}{*}{ Interaction term } & -0.037 & 0.082 & $0.204^{* *}$ \\
\hline & $(0.105)$ & $(0.142)$ & $(0.097)$ \\
\hline Trends & Yes & Yes & Yes \\
\hline Log GDP per-capita & Yes & Yes & Yes \\
\hline Log Local security expenditures & Yes & Yes & Yes \\
\hline Time dummies & Yes & Yes & Yes \\
\hline Department dummies & Yes & Yes & Yes \\
\hline Age-groups dummies & Yes & Yes & Yes \\
\hline R-Squared & 0.707 & 0.689 & 0.707 \\
\hline Number of departments & 29 & 29 & 29 \\
\hline Sample Size & 1250 & 1250 & 1250 \\
\hline
\end{tabular}




\begin{tabular}{lccc}
\hline & \multicolumn{3}{c}{ Dependent Variable: Homicides } \\
\cline { 2 - 4 } & Criterion 1 & Criterion 2 & Criterion 3 \\
\cline { 2 - 4 } & $(1)$ & $(2)$ & $(3)$ \\
\hline & $-0.237^{*}$ & C. RURAL AREAS & \\
Interaction term & $(0.124)$ & $(0.129)$ & -0.020 \\
Trends & Yes & Yes & Yes \\
Log GDP per-capita & Yes & Yes & Yes \\
Log Local security expenditures & Yes & Yes & Yes \\
Time dummies & Yes & Yes & Yes \\
Department dummies & Yes & Yes & Yes \\
Age-groups dummies & Yes & Yes & Yes \\
Number of departments & 29 & 29 & 29 \\
Sample Size & 1250 & 1250 & 1250 \\
\hline
\end{tabular}

${ }^{*} \mathrm{p}<0.10,{ }^{* *} \mathrm{p}<0.05,{ }^{* * *} \mathrm{p}<0.01$

Note: The dependent variable was computed as the number of homicides per 100,000 persons aged between 15 and 64. Robust standard errors are reported in parenthesis. Criteria are based on the following definitions: Criterion 1 makes use of the 1,000 hectares with coca crops destroyed to distinguish the high and low-destruction departments. Criterion 2 uses the comparison between the total number of hectares destroyed and the total number of new ones, where the threshold between the high and low-destruction is determined by whether or not the difference is greater than zero. Finally Criterion 3, which is the baseline in this study, uses the cocadestruction density itself in the producing departments to discriminate between high and low coca crop destruction. Based on this principle, producing departments with more than $19 \%$ coca destruction are classified as high-destruction.

This additional robustness check in table 7 is not intended to make the estimates for the three different classifications comparable with each other, but to look for consistency in terms of significance and direction of the potential causal effects of Plan Colombia on homicide rates. The first noticeable characteristic is that estimates for the first two new criteria (columns 1 and 2), show zero to negative effects not only for the national aggregation but also for urban and rural areas.

The second characteristic is that criteria 1 and 2 tend to show stronger negative effects in all the cases relative to criterion 3 . This is especially noticeable in rural areas where all criteria are coincident in the negative direction of the effect for criterion 1 . These two are coincident even in magnitude and show a reduction of about 20 percentage points in homicides as a result of Plan Colombia. These results show some degree of sensitivity of the results, not in the direction but in the strength of the effects based on different classification alternatives. 
Nevertheless, and as seen before, these results are highly robust to different specifications, program cut-off points, and desegregations.

\subsection{Violent Deaths}

In order to extend the scope of the potential effects of Plan Colombia, in this section, the set of other deaths classified as 'violent' are considered the outcome variable in contrast to natural deaths, deaths from diseases, or homicides. The purpose behind this idea is to establish whether or not the economic resources and the increase in the police forces, even though mainly focused on the eradication of coca crops in rural Colombia, could have had side effects in terms of an improvement in the overall levels of security and confidence in the national institutions during the early post Plan Colombia period. ${ }^{24}$

The first indication of a potential causal relationship between the set up of Plan Colombia and the reduction in violent deaths is the temporal synchronization between the two (as seen in Figure 3) since 1999 and 2000 are the years when the rising trend in violent deaths changes for both low and high-destruction departments. Reductions in the number of violent deaths are expected in those regions where Plan Colombia was more effective in terms of coca crop destruction relative to those in which there was low destruction. Table 8 shows a first exercise, a national aggregation for men and women, where this hypothesis is explored.

Table 8. Effects of Plan Colombia on Violent Deaths. (National Level - Men and Women Comparison)

\begin{tabular}{lcccc}
\hline & \multicolumn{4}{c}{ Dependent Variable: Violent Deaths } \\
\cline { 2 - 5 } & \multicolumn{3}{c}{ Men } & \multicolumn{2}{c}{ Women } \\
\cline { 2 - 5 } & Trends & Trends+Controls & Trends & Trends+Controls \\
\cline { 2 - 5 } & $(1)$ & $(2)$ & $(3)$ & $(4)$ \\
\hline \multirow{2}{*}{ Interaction term } & 0.066 & 0.064 & 0.240 & $0.262^{*}$ \\
Trends & $(0.077)$ & $(0.077)$ & $(0.151)$ & $(0.152)$ \\
Log GDP per-capita & Yes & Yes & Yes & Yes \\
Log Local security expenditures & No & Yes & No & Yes \\
& & Yes & No & Yes \\
& & & & Continúa
\end{tabular}

24 Fajnzylber et al. (1999) and Gaitán (1995) present the main causes of violent crime in Colombia during the last decades of the twentieth century. 


\begin{tabular}{lcccc}
\hline & \multicolumn{4}{c}{ Dependent Variable: Violent Deaths } \\
\cline { 2 - 5 } & \multicolumn{3}{c}{ Men } & \multicolumn{2}{c}{ Women } \\
\cline { 2 - 5 } & Trends & Trends+Controls & Trends & Trends+Controls \\
\cline { 2 - 5 } & Yes & Yes & Yes & Yes \\
\hline Time dummies & Yes & Yes & Yes & Yes \\
Department dummies & Yes & Yes & Yes & Yes \\
Age-groups dummies & 29 & 29 & 29 & 29 \\
Number of departments & 1250 & 1250 & 1250 & 1250 \\
Sample Size & & & & \\
\hline
\end{tabular}

${ }^{*} \mathrm{p}<0.10,{ }^{* *} \mathrm{p}<0.05,{ }^{* * *} \mathrm{p}<0.01$

Note: The dependent variable was computed as the number of violent deaths per 100,000 persons aged between 15 and 64. Robust standard errors are reported in parenthesis.

Results are divided into two groups of the population, men in columns (1) and (2) and women in columns (3) and (4), where each gender has two models with trends and two with trends plus controls. Estimates show different results for both men and women with zero to positive and no significant effects on the male population, and with an unexpected positive and strong effect for women. According to these results, after the implementation of Plan Colombia, violent deaths affecting women increased by about 25 percentage points in those regions with high-destruction of coca crops relative to those regions where low levels of destruction were reported. Remember that Plan Colombia focused its attention, and most of its economic and military resources, on the countryside where coca crops are located. Thus, the next exercise includes a disaggregation of the results based on the two areas of residence, urban and rural, in order to better understand the previous results.

Table 9. Effects of Plan Colombia on Violent Deaths. (Urban and Rural Areas Comparisons)

\begin{tabular}{|c|c|c|c|}
\hline \multicolumn{4}{|c|}{ Dependent Variable: Violent Deaths } \\
\hline & Men & & Women \\
\hline Trends & Trends+Controls & Trends & Trends+Controls \\
\hline
\end{tabular}

(1)

0.142

Interaction term

Trends
(2)

(3)

(4)

\section{A. URBAN AREAS}

$0.142 \quad 0.449^{* *}$

$(0.203)$

(0.100)

Yes
$0.462^{* *}$

Yes 


\begin{tabular}{|c|c|c|c|c|}
\hline & \multicolumn{4}{|c|}{ Dependent Variable: Violent Deaths } \\
\hline & \multicolumn{2}{|r|}{ Men } & \multicolumn{2}{|r|}{ Women } \\
\hline & Trends & Trends+Controls & Trends & Trends+Controls \\
\hline & (1) & (2) & (3) & (4) \\
\hline Log GDP per-capita & No & Yes & No & Yes \\
\hline $\begin{array}{l}\text { Log Local security } \\
\text { expenditures }\end{array}$ & No & Yes & No & Yes \\
\hline Time dummies & Yes & Yes & Yes & Yes \\
\hline Department dummies & Yes & Yes & Yes & Yes \\
\hline Age-groups dummies & Yes & Yes & Yes & Yes \\
\hline Number of departments & 29 & 29 & 29 & 29 \\
\hline \multirow[t]{2}{*}{ Sample Size } & 1250 & 1250 & 1250 & 1250 \\
\hline & \multicolumn{4}{|c|}{ B. RURAL AREAS } \\
\hline \multirow{2}{*}{ Interaction term } & $-0.464^{* *}(\mathrm{a})$ & $-0.462^{* *}(a)$ & 0.087 & 0.084 \\
\hline & $(0.204)$ & $(0.204)$ & $(0.275)$ & $(0.279)$ \\
\hline Trends & Yes & Yes & Yes & Yes \\
\hline Log GDP per-capita & No & Yes & No & Yes \\
\hline $\begin{array}{l}\text { Log Local security } \\
\text { expenditures }\end{array}$ & No & Yes & No & Yes \\
\hline Time dummies & Yes & Yes & Yes & Yes \\
\hline Department dummies & Yes & Yes & Yes & Yes \\
\hline Age-groups dummies & Yes & Yes & Yes & Yes \\
\hline Number of departments & 29 & 29 & 29 & 29 \\
\hline Sample Size & 1250 & 1250 & 1250 & 1250 \\
\hline
\end{tabular}

${ }^{*} \mathrm{p}<0.10,{ }^{* *} \mathrm{p}<0.05,{ }^{* * *} \mathrm{p}<0.01$

Note: The dependent variable was computed as the number of violent deaths per 100,000 persons aged between 15 and 64. Robust standard errors are reported in parenthesis.

(a) Because non-convergence in the Negative Binomial Model, the alternative Posisson estimates are reported.

Following a similar strategy, a more extensive disaggregation of the population is presented in Table 9, which shows the estimates for the effects of the program on violent death rates for urban (panel A) and rural populations (panel B). Results reveal some interesting facts. The first one is that after disaggregating the population into urban and rural, the positive and significant effect seen in the national results remained the same for urban women with increases of about 45 percentage points in violent deaths. The second result was a clear and significant 46 percentage point reduction in violent deaths of men, which is consistent 
with the two different specifications in the model-trends and trends+controls. These results seem to be consistent in terms of the reduction of violent deaths of men since rural men were usually more active agents in the conflict. The other part of the story is the presumed cross-gender and spatial displacement effect where women living in urban areas suffered increases in the number of violent deaths. In order to establish how robust these results are and to capture any lagged effect from the program, the post-Plan Colombia period was extended one additional year.

Results are reported in columns (2) and (4) of Table 10 and show that consistently significant but smaller effects were found when extending the period beyond 2002 (columns 1 and 3). Nevertheless, a skeptic might argue that the previous findings, even though based on a clear distinction between the high and low-destruction groups, are the result of the criterion by which the comparison groups were chosen instead of the true effects of the program. As in homicides, in order to address this possibility and to even more stringently ensure that like is being compared with like respecting groups of departments, the other two coca-destruction criteria were used. Table 11 shows estimates based on the 1,000 hectares destroyed in column (1) and on the positive net number of hectares destroyed in column (2). Column (3) is left for comparison with the baseline criteria.

Table 10. Effects of Plan Colombia on Violent Deaths. (Comparison between Two Different Post-Policy Periods)

\begin{tabular}{lcccc}
\hline & \multicolumn{4}{c}{ Dependent Variable: Violent Deaths } \\
\cline { 2 - 5 } & \multicolumn{3}{c}{ Men } & \multicolumn{2}{c}{ Women } \\
\cline { 2 - 5 } & Post-policy: & Post-policy: & Post-policy: & Post-policy: \\
& $2000-2002$ & $2000-2003$ & $2000-2002$ & $2000-2003$ \\
\cline { 2 - 5 } & & $(1)$ & $(3)$ & $(4)$ \\
\hline & 0.142 & 0.131 & $0.462^{* *}$ & $0.380^{* *}$ \\
Interaction term & $(0.100)$ & $(0.081)$ & $(0.203)$ & $(0.171)$ \\
Trends & Yes & Yes & Yes & Yes \\
Log GDP per-capita & Yes & Yes & Yes & Yes \\
Log Local security & Yes & Yes & Yes & Yes \\
expenditures & & & & Yes \\
Time dummies & Yes & Yes & Yes & Yes \\
Department dummies & Yes & Yes & Yes & Continúa
\end{tabular}




\begin{tabular}{|c|c|c|c|c|}
\hline & \multicolumn{4}{|c|}{ Dependent Variable: Violent Deaths } \\
\hline & \multicolumn{2}{|c|}{ Men } & \multicolumn{2}{|c|}{ Women } \\
\hline & $\begin{array}{l}\text { Post-policy: } \\
2000-2002\end{array}$ & $\begin{array}{l}\text { Post-policy: } \\
2000-2003\end{array}$ & $\begin{array}{l}\text { Post-policy: } \\
2000-2002\end{array}$ & $\begin{array}{l}\text { Post-policy: } \\
2000-2003\end{array}$ \\
\hline & $(1)$ & (2) & (3) & (4) \\
\hline Age-groups dummies & Yes & Yes & Yes & Yes \\
\hline Number of departments & 29 & 29 & 29 & 29 \\
\hline \multirow[t]{2}{*}{ Sample Size } & 1250 & 1500 & 1250 & 1500 \\
\hline & \multicolumn{4}{|c|}{ B. RURAL AREAS } \\
\hline \multirow{2}{*}{ Interaction term } & $-0.462^{* *}(\mathrm{a})$ & $-0.430^{* *}$ & 0.084 & -0.012 \\
\hline & $(0.204)$ & $(0.215)$ & $(0.279)$ & $(0.238)$ \\
\hline Trends & Yes & Yes & Yes & Yes \\
\hline Log GDP per-capita & Yes & Yes & Yes & Yes \\
\hline $\begin{array}{l}\text { Log Local security } \\
\text { expenditures }\end{array}$ & Yes & Yes & Yes & Yes \\
\hline Time dummies & Yes & Yes & Yes & Yes \\
\hline Department dummies & Yes & Yes & Yes & Yes \\
\hline Age-groups dummies & Yes & Yes & Yes & Yes \\
\hline Number of departments & 29 & 29 & 29 & 29 \\
\hline Sample Size & 1250 & 1500 & 1250 & 1500 \\
\hline
\end{tabular}

${ }^{*} \mathrm{p}<0.10,{ }^{* *} \mathrm{p}<0.05,{ }^{* * *} \mathrm{p}<0.01$

Note: The dependent variable was computed as the number of violent deaths per 100,000 persons aged between 15 and 64. Robust standard errors are reported in parenthesis. Given the different number of observations used to compute the estimates in columns (1) and (2) and (3) and (4), any comparison between them must be done carefully.

(a) Because non-convergence in the Negative Binomial Model, the alternative Posisson estimates are reported.

Table 11 presents comparisons for gender-aggregated data from national, urban, and rural areas. A first view at the national level in panel A allows us to see consistent estimates in most of the cases in terms of direction, magnitude, and significance where even the standard errors are also very close to each other. This means that, at the national level and for aggregations across gender and areas of residence, no effects on violent deaths seem to have come from Plan Colombia in areas with high coca destruction relative to low destruction regions. 
Table 11. Effects of Plan Colombia on Violent Deaths. (Comparison between Three Different Treatment/Control Definitions)

\begin{tabular}{|c|c|c|c|}
\hline & \multicolumn{3}{|c|}{ Dependent Variable: Violent Deaths } \\
\hline & Criterion 1 & Criterion 2 & Criterion 3 \\
\hline & (1) & (2) & (3) \\
\hline & \multicolumn{3}{|c|}{ A. NATIONAL } \\
\hline \multirow{2}{*}{ Interaction term } & 0.117 & 0.100 & 0.108 \\
\hline & $(0.078)$ & $(0.077)$ & $(0.074)$ \\
\hline Trends & Yes & Yes & Yes \\
\hline Log GDP per-capita & Yes & Yes & Yes \\
\hline $\begin{array}{l}\text { Log Local security } \\
\text { expenditures }\end{array}$ & Yes & Yes & Yes \\
\hline Time dummies & Yes & Yes & Yes \\
\hline Department dummies & Yes & Yes & Yes \\
\hline Age-groups dummies & Yes & Yes & Yes \\
\hline Number of departments & 29 & 29 & 29 \\
\hline \multirow[t]{2}{*}{ Sample Size } & 1250 & 1250 & 1250 \\
\hline & \multicolumn{3}{|c|}{ B. URBAN AREAS } \\
\hline \multirow{2}{*}{ Interaction term } & 0.030 & $0.214^{* *}$ & $0.222^{* *}$ \\
\hline & $(0.101)$ & $(0.097)$ & $(0.092)$ \\
\hline Trends & Yes & Yes & Yes \\
\hline Log GDP per-capita & Yes & Yes & Yes \\
\hline $\begin{array}{l}\text { Log Local security } \\
\text { expenditures }\end{array}$ & Yes & Yes & Yes \\
\hline Time dummies & Yes & Yes & Yes \\
\hline Department dummies & Yes & Yes & Yes \\
\hline Age-groups dummies & Yes & Yes & Yes \\
\hline Number of departments & 29 & 29 & 29 \\
\hline \multirow[t]{2}{*}{ Sample Size } & 1250 & 1250 & 1250 \\
\hline & \multicolumn{3}{|c|}{ C. RURAL AREAS } \\
\hline \multirow{2}{*}{ Interaction term } & 0.007 & -0.017 & -0.020 \\
\hline & $(0.135)$ & $(0.135)$ & $(0.131)$ \\
\hline Trends & Yes & Yes & Yes \\
\hline Log GDP per-capita & Yes & Yes & Yes \\
\hline
\end{tabular}




\begin{tabular}{lccc}
\hline & \multicolumn{3}{c}{ Dependent Variable: Violent Deaths } \\
\cline { 2 - 4 } & Criterion 1 & Criterion 2 & Criterion 3 \\
\cline { 2 - 4 } & $(1)$ & $(2)$ & $(3)$ \\
\hline $\begin{array}{l}\text { Log Local security } \\
\text { expenditures }\end{array}$ & Yes & Yes & Yes \\
Time dummies & Yes & Yes & Yes \\
Department dummies & Yes & Yes & Yes \\
Age-groups dummies & Yes & Yes & Yes \\
Number of departments & 29 & 29 & 29 \\
Sample Size & 1250 & 1250 & 1250 \\
\hline
\end{tabular}

${ }^{*} \mathrm{p}<0.10,{ }^{* *} \mathrm{p}<0.05,{ }^{* * *} \mathrm{p}<0.01$

Note: The dependent variable was computed as the number of violent deaths per 100,000 persons aged between 15 and 64. Robust standard errors are reported in parenthesis. Criteria are based on the following definitions: Criterion 1 makes use of the 1,000 hectares with coca crops destroyed to distinguish between the high and lowdestruction groups of departments. Criterion 2 uses the comparison between the total number of hectares destroyed and the total number of new ones, where the threshold between the high and low-destruction is determined by whether or not the difference is greater than zero. Finally Criterion 3, which is the baseline in this study, uses the coca-destruction density itself in the producing departments to discriminate between high and low coca crop destruction. Based on this principle, producing departments with more than $19 \%$ coca destruction are classified as high-destruction.

Once the analysis is carried out separately for urban and rural areas (panels B and $C$ respectively), results show the same strong consistency for the different criteria with positive estimates for urban areas and negative for the rural ones. The difference is that positive estimates in the urban areas are significant and all negative effects in rural regions are not. Two important conclusions can be drawn from the former exercises. First, the effects on violent deaths are all consistent with a varied set of specifications. And second, disaggregation of the population by gender and areas of residence is of great importance since differentiated effects might be found behind national and/or gender aggregations.

\subsection{Additional Robustness Checks}

The peculiarity of drug production and trafficking in Colombia as well as the particular characteristics of the program made it possible to extend the robustness checks even further. This was done to provide stronger and more conclusive evidence supporting not only the former results in which Plan Colombia had no effect on homicides and different effects on violent deaths but also the identification assumptions. 
To do so I exploited the fact that only 23 out of the 33 departments in the country had significant levels of coca cultivation during the period under study as well as the fact that the policy had disproportionate results in those coca-producing departments. These factors made it possible to classify the departments into three different groups: high-coca-destruction, low-coca-destruction, and non-coca-producing departments where, under the baseline classification, the first group corresponds to the treatment group and the last two to the control groups. The first estimate is an exercise consisting of a comparison between two additional versions of the baseline model with the definition of the control group as the only variation.

Table 12. Effects of Plan Colombia on Homicides and Violent Deaths. (Comparison between Three Different Control Group Definitions)

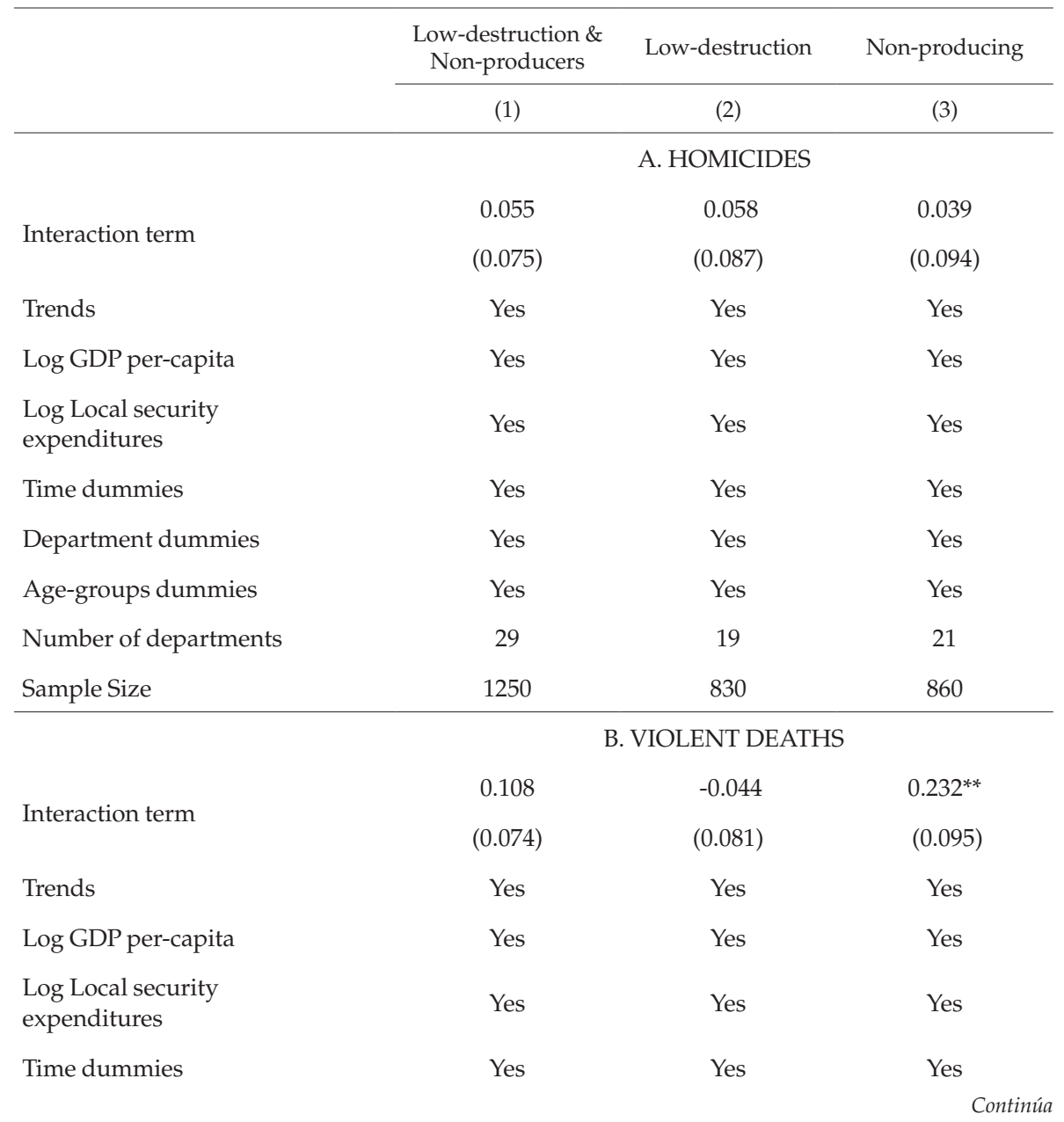




\begin{tabular}{lccc}
\hline & $\begin{array}{c}\text { Low-destruction \& } \\
\text { Non-producers }\end{array}$ & Low-destruction & Non-producing \\
\cline { 2 - 4 } & $(1)$ & $(2)$ & $(3)$ \\
\hline Department dummies & Yes & Yes & Yes \\
Age-groups dummies & Yes & Yes & Yes \\
Number of departments & 29 & 19 & 21 \\
Sample Size & 1250 & 830 & 860 \\
\hline
\end{tabular}

${ }^{*} \mathrm{p}<0.10,{ }^{* *} \mathrm{p}<0.05,{ }^{* * *} \mathrm{p}<0.01$

Note: The dependent variable was computed as the corresponding number of homicides and violent deaths per 100,000 persons aged between 15 and 64. Robust standard errors are reported in parenthesis. The results correspond to the national (urban and rural areas) and gender (men and women) aggregations for the post-policy period 2000/2002. Estimates were computed based on equation (1) including trends and controls on local security expenditures and GDP per-capita. Column (1) corresponds to the estimates using the baseline definition control group (low-destruction + non-producing departments); column (2) shows the estimates for the specification using only low-destruction departments as a control group; and column (3) corresponds to estimates using non-producing departments as a control group. All the specifications use high-destruction departments as the treatment group. Given the different number of observations used to compute the estimates for the three different specifications, direct comparisons cannot be carried out.

Table 12 shows three different versions for both homicides (panel A) and violent deaths (panel B) of the causal effects of Plan Colombia on the outcome variables. Column (1) reports the estimates corresponding to the baseline specification where the control group of departments consists of the low-destruction and non-producing departments. Columns (2) and (3) show the estimates of a model in which low-coca-destruction departments and non-producing departments are dealt with separately as the control groups. ${ }^{25}$ These results show once again that when non-producers alone are used as control groups, consistency in terms of no significant effects on homicides and positive significant effects on violent deaths improves. Finally Appendix B reports the results of a test that seeks to establish whether or not the unconfoundedness assumption holds. ${ }^{26}$ One way to indirectly approximate this test is by using two distinct control groups and choosing one of them to be a treatment and the other a control group. The way the test works is that the effect should be zero in any case given that none of them is really treated. As can be seen in Appendix B, the estimates show no significant estimates for either homicides (panel A) or violent deaths (panel B)

25 Note that estimates in the three columns have to be carefully analyzed since three different specifications of the control group imply three different sample sizes.

26 This assumption states that, conditional on a set of covariantes, the choice of the treatment and control groups is independent of the outcome variable. 
for national aggregations and urban or rural areas. Thus I found no reason to believe that conditional independence does not hold in this case.

\section{Summary and Conclusions}

In this paper, the effects of Plan Colombia on homicides and violent deaths were analyzed. This policy intervention was fully implemented in 2000 under Colombian/American cooperation which was mainly focused on the reduction of coca cultivation in the country. Although additional measures such as promoting social and economic justice and increasing security and not just reducing the supply of cocaine were considered for this initiative, the truth is that either the program fell short in implementing measures aimed at reducing crimes, or that was never its main purpose. In fact Mejía and Restrepo (2009) and Gaviria and Mejía (2011) state that once the cooperation of the U.S. government started in 2000, the fundamental objectives of the program changed radically since the Americans had conditioned aid to reducing the supply of illegal drugs and not to reducing levels of insecurity in Colombia.

The particular characteristics growing out of the implementation of Plan Colombia made it possible to analyze the causation between reducing coca cultivation and violent deaths by looking at the impact of additional economic/ military resources on the reduction of homicides and other violent deaths. To do so, the number of deaths before and after the policy implementation in the regions mainly affected (with high-destruction of coca crops) as compared to those where the impact was lower (with low-destruction of coca crops) was analyzed. Care was taken to consider only the years for which there was no overlapping with the security program which started late in 2002 (specifically the so called Democratic Security Policy and peace-seeking talks between the Government and the paramilitaries).

The estimates derived from a number of empirical strategies show that while there is no evidence of any positive or negative effect on homicides, there are differentiated positive/negative effects on violent deaths when disaggregated gender and areas of residence are considered. To be specific, even though the effect as a whole seems to be an increase in violent deaths, this is the case only for women living in urban areas. In contrast, for men in the country, the results revealed a reduction in the number of violent deaths. Even though there is clear and uncontroversial evidence that the goal set by the Colombian/American cooperation was achieved - in terms of a reduction in the number of hectares with coca crops but not in terms of reducing the supply of cocaine-no evidence was found of any significant effect of this initiative on the reduction of homicides. 
The main contribution of this paper is to present new and conclusive evidence on the causal relation between Plan Colombia and violent deaths. Previous studies had shown a negative and significant relationship between them; however, this study made an effort to overcome some potential obstacles in terms of the identification strategy and, in particular, the set up of the post-policy period, from which it is clear that no causal relationship existed between Plan Colombia and the reduction of homicides during the program's onset.

\section{References}

Acevedo, B., Bewley-Taylor, D. \& Youngers, C. (2008). Ten Years of Plan Colombia: An Analytic Assestment, Briefing Paper Sixteen, The Berckley Foundation Drug policy Programme.

Angrist, J. \& Kugler, A. (2008). Rural Windfall or a New Resource Curse? Coca, Income, and Civil Conflict in Colombia. The Review of Economics and Statistics, XC, 191-215.

Barón, J. (2008). Did Plan Colombia Reduce Homicides. (Ph.D. dissertation, Chapter 3, 42-78, Australian National University, Canberra).

Barón, J. (2009). El homicidio en los tiempos del Plan Colombia. Documentos de trabajo sobre economía regional, 115. CEER. Banco de la República.

Becker, G. (1968). Crime and Punishment: An Economic Approach. The Journal of Political Economy, 76, 169-217.

Cameron, S. (1988). The Economics of Crime Deterrence: A Survey of Theory and Evidence. Kyklos - International Review for Social Sciences, 41, 301-323.

Contraloría General de la Nación. (2001). Plan Colombia. Primer informe de evaluación, Bogotá: Contraloría General de la Nación.

Deas, M. (2002). Acerca del Plan Colombia. Sociedad y Economía, 1, 249-258.

Di Tella, R. \& Schargrodsky, E. (2004). Do Police Reduce Crime? Estimates Using the Allocation of Police Forces after a Terrorist Attack. The American Economic Review, 94, 115-133.

Díaz, A. M. \& Sanchez, F. (2004). Geography of Illicit Crops and Armed Conflict in Colombia (in Spanish). Working Paper 18, CEDE, Universidad de los Andes.

Draca, M., Machin, S. \& Witt, R. (2011). Panic on the Streets of London: Police, Crime and the July 2005 Terror Attacks. American Economic Review, 101, 2157-2181.

Echandía, C. (1997). Dimensión regional del homicidio en Colombia. Coyuntura Social, 17, 89-105. 
Echeverry, J. C. \& Zeinab, P. (1998). Por qué la justicia no responde al crimen: el caso de la cocaína en Colombia. In Cárdenas, M. \& Steiner, R., (Comp.) Corrupción, crimen y justicia. Una perspectiva económica. TM Editores and LACEA: Bogotá.

Ehrlich, I. (1974). Participation in Illegitimate Activities - An Economic Analysis, In Becker, G. \& Landes, W. (Eds.), The Economics of Crime and Punishment, 68-134. New York: Columbia University Press.,

Fajnzylber, P., Lederman, D., \& Loayza, N. (1999). ¿Qué causa el crimen violento? In Cárdenas, M., \& Steiner, R., (Comp) Corrupción, crimen y justicia. Una perspectiva económica. Bogota: TM Editores and LACEA.

Gaitán, F. (1995). Una indagación sobre las causas de la violencia en Colombia. In Deas, M., Gaitán, F. Dos ensayos especulativos sobre la violencia en Colombia. Bogotá: FONADE-DNP.

GAO. (2008). Plan Colombia: Drug reduction goals were not fully met, but Security has improved; U.S. agencies need more detailed plans for reducing assistance. Washington, DC.: United States Govenment Accountability Office.

Gaviria, A. \& Mejía, D. (2011). Políticas Antidroga en Colombia: Éxitos, Fracasos y Extravíos. Bogotá: Universidad de los Andes.

Kawell, J. (2001). Closing the Latin American Air-Bridge: A Disturbing History. Foreign Policy, Info Focus. Retrieved from http://fpif.org/closing_the_latin_american_air-bridge_a_disturbing_history /

Klick, J. \& Tabarrok, A. (2005). Using Terror Alert Levels to Estimate the Effect of Police on Crime. Journal of Law and Economics, XLVIII, 267-279.

Machin, S. \& Marie, O. (2011). Crime and Police Resources: The Street Crime Initiative. Journal of the European Economic Association, 9, 678-701.

Mejía, D. \& Posada, C. E. (2008). Cocaine Production and Trafficking: What Do We Know? Policy Research Working Paper No. 4618, The World Bank.

Mejía, D. \& Restrepo, P. (2009). The War on Illegal Drug Production and Trafficking: An Economic Evaluation of Plan Colombia, Working Paper. 387, Stanford Center for International Development, Stanford University.

Peceny, M. \& Durnan, M. (2006). The FARC's Best Friend: U.S. Antidrug Policies and the Deepening of Colombia's Civil War in the 1990s. Latin American Politics and Society, 48, 95-116.

Pérez, G.J. (2012a) Primera versión de la política de seguridad democrática: ¿Se cumplieron los objetivos?, Revista de Economía del Rosario, 15, 179-213.

Pérez, G. J. (2012b). The Democratic Security Policy: Socioeconomic Effects in the Rural Areas, 2002-2006. Borradores de Economía 718, Banco de la República.

Ramírez, M. C. (2005). Aerial Spraying and Alternative Development in Plan Colombia: Two sides of the Same Coin or Two Contested Policies?. Harvard Review of Latin America, 52-55. 
Rocha, R., Coronado, H. \& Martínez, H. (2010). Coca y deforestación en Colombia, Departamento Nacional de Planeación (DNP), [mimeo].

Rubio Mauricio (2000). Violencia y conflicto en los noventa. Coyuntura Social, 22, 151-186.

United Nations Office for Drug Control (UNODC). (2009). World Drug Report 2009. New York: United Nations.

Appendix A. Coca Cultivation in Colombia - Number of Hectares, 1999-2003

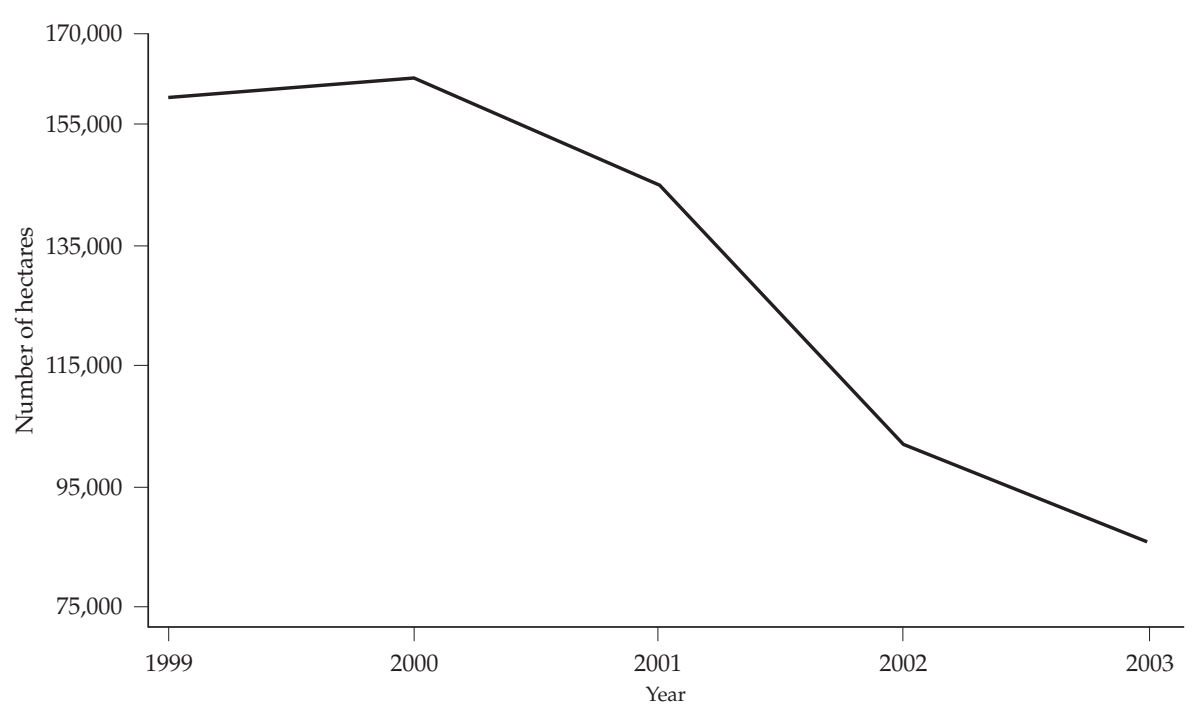

Note: United Nations office for Drug Control (UNODC) and the Government of Colombia.

Appendix B. Unconfoundedness Test for the Effects of Plan Colombia on Homicides and Violent Deaths

(Comparison Across National, Urban, and Rural Areas)

\begin{tabular}{lccc}
\hline & National & Urban Areas & Rural Areas \\
\cline { 2 - 4 } & $(1)$ & $(2)$ & $(3)$ \\
\hline \multirow{3}{*}{ Interaction term } & & A. HOMICIDES & \\
& -0.001 & -0.004 & -0.218 \\
Trends & $(0.106)$ & $(0.143)$ & $(0.192)$ \\
& Yes & Yes & Yes Continúa
\end{tabular}




\begin{tabular}{lccc}
\hline & National & Urban Areas & Rural Areas \\
\cline { 2 - 4 } & $(1)$ & $(2)$ & $(3)$ \\
\hline Log GDP per-capita & Yes & Yes & Yes \\
Log Local security expenditures & Yes & Yes & Yes \\
Time dummies & Yes & Yes & Yes \\
Department dummies & Yes & Yes & Yes \\
Age-groups dummies & Yes & Yes & Yes \\
Number of departments & 18 & 18 & 18 \\
Sample Size & 810 & 810 & 810 \\
\hline & & B. VIOLENT DEATHS & \\
Interaction term & 0.286 & 0.246 & 0.252 \\
Trends & $(0.219)$ & $(0.240)$ & $(0.252)$ \\
Log GDP per-capita & Yes & Yes & Yes \\
Log Local security expenditures & Yes & Yes & Yes \\
Time dummies & Yes & Yes & Yes \\
Department dummies & Yes & Yes & Yes \\
Age-groups dummies & Yes & Yes & Yes \\
Number of departments & Yes & Yes & Yes \\
Sample Size & 18 & 18 & 18 \\
\hline
\end{tabular}

${ }^{*} \mathrm{p}<0.10,{ }^{* *} \mathrm{p}<0.05,{ }^{* * *} \mathrm{p}<0.01$

Note: The dependent variable was computed as the corresponding number of homicides and violent deaths per 100,000 persons aged between 15 and 64. Robust standard errors are reported in parenthesis. The results correspond to gender (men and women) aggregations for the post-policy period 2000/2002. Estimates were computed including trends and controls on local security expenditures and GDP per-capita. In this case, regressions between two different control groups-low-coca-destruction and non-producing-were carried out. 